\title{
The Lower Cretaceous succession of the northwestern Barents Shelf: onshore and offshore correlations
}

\author{
S.-A. Grundvåg ${ }^{1}$, D. Marin ${ }^{2}$, B. Kairanov ${ }^{2}$, K.K. Śliwińska ${ }^{3}$, H. Nøhr-Hansen ${ }^{3}$, A. Escalona ${ }^{2} \&$ S. \\ Olaussen $^{4}$ \\ ${ }^{l}$ Department of Geosciences, UiT - The Arctic University of Norway, P.O. Box 6050 Langnes, 9037 Troms $\phi$, \\ Norway. \\ ${ }^{2}$ Department of Petroleum Engineering, University of Stavanger, 4036 Stavanger, Norway. \\ ${ }^{3}$ Geological Survey of Denmark and Greenland (GEUS), Øster Voldgade 10, DK-1350 Copenhagen K Denmark. \\ ${ }^{4}$ Department of Arctic Geology, University Centre in Svalbard, P.O. Box 156, 9171 Longyearbyen, Norway.
}

*Corresponding author.

E-mail address: sten-andreas.grundvag@uit.no

\section{ABSTRACT}

The Lower Cretaceous succession in the Barents Sea is listed as a potential play model by the Norwegian Petroleum Directorate. Reservoirs may occur in deep to shallow marine clastic wedges located in proximity to palaeo-highs and along basin margins. In addition, shelf-prism-scale clinoforms with high amplitude anomalies in their top- and bottomsets have been reported from reflection seismic but they have never been drilled. In Svalbard, the exposed northwestern corner of the Barents Shelf, Lower Cretaceous strata of shelfal to paralic origin occur, and includes the Rurikfjellet (Valanginian-Hauterivian/lowermost Barremian), Helvetiafjellet (lower Barremian-lower Aptian) and Carolinefjellet formations (lower Aptian-middle Albian). By combining sedimentological outcrop studies and dinocyst analyses with offshore seismic and well ties, this study investigate the link between the onshore strata and the offshore clinoforms. Age-vise, only three (S1-S3) of the seismic sequences defined in the offshore areas correlate to the onshore strata; S1 correspond to the Rurikfjellet Formation, S2 to the Helvetiafjellet Formation and the lower Carolinefjellet Formation, and S3 to the upper Carolinefjellet Formation. Offshore, all three sequences contain generally southward prograding shelf-prism-scale clinoforms. A lower Barremian subaerial unconformity defines the base of the Helvetiafjellet Formation, and its extent indicates that most of the Svalbard platform was exposed and acted as a bypass zone in the early Barremian. Onshore palaeo-current directions is generally towards the SE, roughly consistent with the clinoform accretion-direction 
towards the $\mathrm{S}$. The local occurrence of a $150 \mathrm{~m}$ thick succession of gravity flow deposits transitionally overlain by prodelta slope to delta front deposits in the Rurikfjellet Formation, may indicate that shelfedges also developed in Svalbard. The late Hauterivian age of theses deposits potentially highlights the inferred offlapping nature of the Lower Cretaceous strata as they predate the lower Barremian unconformity, and thus record a hitherto unknown regression in Svalbard. The presence of the lower Barremian subaerial unconformity in Svalbard, the general southeastward palaeo-current directions, and the age-equivalent clinoform-packages south of Svalbard, suggests that the onshore and offshore strata is genetically linked and was part of the same palaeo-drainage system.

, whi.

Keywords: Early Cretaceous, clinoforms, Barents Sea geology, dinoflagellate biostratigraphy

\section{Introduction}

After several technical discoveries in clastic wedges of deep to shallow marine origin (e.g. Stewart et al., 1995; Seldal, 2005; Sattar et al., 2017), the Lower Cretaceous have been listed as one of several play models on the Barents Shelf by the Norwegian Petroleum Directorate. Lower Cretaceous shelf-margin-scale clinoforms containing prolific hydrocarbon-reservoirs in their shelf top-sets and base-of-slope toe-sets occur in the West Siberian Basin (Pinous et al., 1999, 2001; Ulmishek, 2003) and the Alaskan North Slope (Houseknecht et al., 2009). The Lower Cretaceous palaeogeography and basin development on the Barents Shelf are not yet fully understood. Lower Cretaceous clinoforms have been reported from seismic reflection data on the Bjarmeland Platform and in the Fingerdjupet Subbasin (Henriksen et al., 2011; Marin and Escalona, 2014; Marin et al., 2016a, 2016b). Several studies have discussed the stratigraphic and lateral development of the Lower Cretaceous in Svalbard (e.g. Steel et al., 1978; Nemec et al., 1988; Nemec, 1992; Gjelberg and Steel, 1995, 2013; Midtkandal et al., 2007; 2008), and some have invoked a genetic link between the onshore and the offshore depositional systems (Århus et al., 1990; Steel et al., 2000; Midtkandal and Nystuen, 2009; Grundvåg and Olaussen, 2017). However, to date no studies have documented such a link due to a combination of limited data, long-distance correlations, poor age constrains and the lack of preserved Lower Cretaceous strata in parts of the northern Barents Sea. 
This paper aims to shed new light on the onshore-offshore correlation of the Lower Cretaceous mainly in the northwestern part of the Barents Shelf (Fig. 1) by combining new biostratigraphic data, conventional outcrop data from Svalbard, and an offshore dataset consisting of seismic and geophysical well data. This study is part of the industry funded LoCrA (Lower Cretaceous basin studies in the Arctic, for more details see http://locra.ux.uis.no) consortium, and this paper summarizes some of our preliminary geological results and argue for a genetic link between the onshore and offshore depositional systems.

\section{Geological framework}

\subsection{Study area and tectonic setting}

Svalbard is an Arctic archipelago which represents the uplifted and exposed northwest corner of the Barents Shelf (Fig. 1). The shelf is bounded to the west by a sheared margin, to the north by a rifted (now passive) continental margin, and to the south and east by the Baltic Shield and Novaya Zemlya, respectively (Fig. 1). The latter separates it from the prolific Kara Sea region. Mesozoic strata are well preserved in Svalbard and occur in several basins and platform areas offshore, providing a unique opportunity to correlate onshore and offshore strata (e.g. Nødtvedt et al., 1992; Henriksen et al., 2011). 


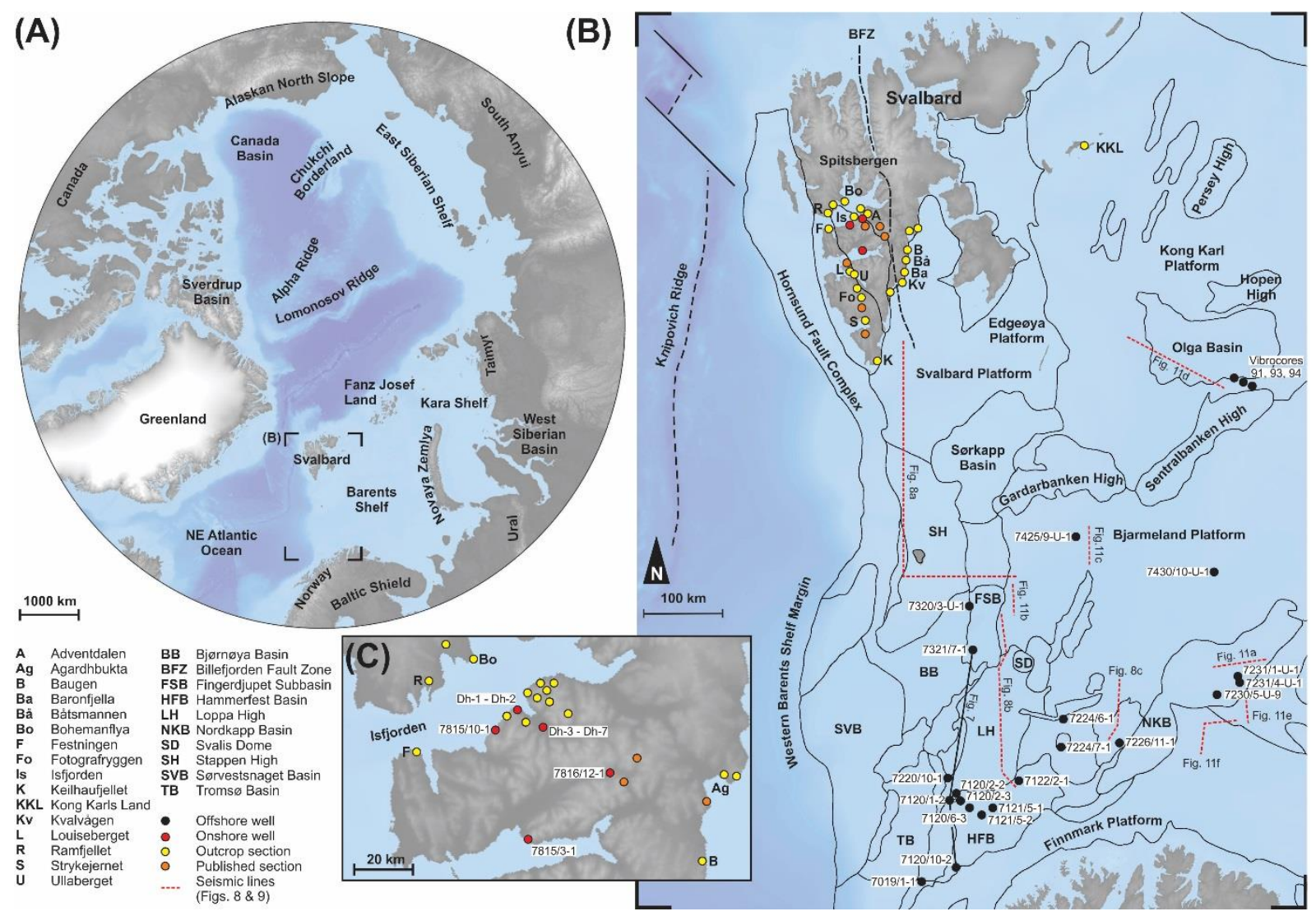

Fig. 1. (A) Circum-Arctic map showing the location of the study area on the Barents Shelf (dashed rectangle) and some of the main tectonic features of the Arctic Basin. (B) Map of the study area showing the main structural elements (based on Grogan et al., 1999 and Henriksen et al., 2011) and location of the investigated outcrops, and onshore and offshore well data used in this study. The position of the seismic lines used in the study are shown in inset maps accompanying the seismic cross-sections. (C) Map of Nordenskiöld Land in Central Spitsbergen showing the location of some outcrop sections and onshore wells used in this study. Bathymetry data is from IBCAO (http://www.ngdc.noaa.gov/mgg/bathymetry/arctic/downloads.html).

The Lower Cretaceous in the northern Barents Shelf, including Svalbard, was deposited in a subsiding epicontinental sag basin (e.g. Faleide et al., 2008; Henriksen et al., 2011; Fig. 2). Some minor fault activity is indicated on the Svalbard platform by stratal thickness variations across regional lineaments and syn-sedimentary collapse features in proximity to these (Steel and Worsley, 1984;

Nemec et al., 1988; Onderdonk and Midtkandal, 2010). A shelf-edge setting have also been invoked to explain the presence of the collapse features on the east coast of Spitsbergen (Steel et al., 2000;

Gjelberg and Steel, 2013). The region was heavily influenced by differential uplift and magmatism related to the opening of the Canada Basin in Late Jurassic to Early Cretaceous times (Maher, 2001;

Grantz et al., 2011). In Svalbard, Franz Josef Land, and nearby shelf areas, the magmatic activity 
peaked in the Barremian to early Aptian (Corfu et al., 2013; Polteau et al., 2015) with the development of circum-Arctic dyke swarms and local volcanism (Grogan et al., 2000; Senger et al., 2014; Fig. 2). Some workers have also suggested a hot spot origin for the Canada Basin as the Iceland hot spot transited the Polar region in the latest part of the Early Cretaceous to Late Cretaceous (Lawver and Muller, 1994; Lawver et al., 2002). In Svalbard, early Barremian uplift and southward tilting of the shelf created a regionally-extensive subaerial unconformity (Gjelberg and Steel, 1995, 2013; Maher, 2001)

The southwestern Barents Shelf is characterized by several N-S to NE-SW-trending rift basins and structural highs belonging to the Mesozoic North Atlantic rift system (e.g. Dalland, 1981; Doré et al., 1999; Torsvik et al., 2002, Faleide et al., 1993, 2008; Fig. 2). Although some minor fault displacement is evident in the middle Jurassic, the main phase of extensional faulting took place in the Early Cretaceous with a rift climax in the Hauterivian (Faleide et al., 1993; Doré et al., 1999). In this period the rift basins experienced significant subsidence resulting in thick successions of Lower Cretaceous deposits (e.g. Faleide et al., 1993). The submerged structural highs experienced sediment starvation, and condensed carbonate successions developed locally (Smelror et al., 1998). Compressional tectonics leading to inversion and vertical movement of some structural elements also influenced the basin development in the Early Cretaceous (Faleide et al., 1993; Gabrielsen et al., 1997; Grogan et al. 1999; Indrevær et al., 2016), particularly in the northeastern Barents Shelf, including Kong Karls Land, where a series of SW-NE-trending anticlines formed and locally controlled the palaeo-drainage (Grogan et al., 1998; Kairanov et al., 2015). 


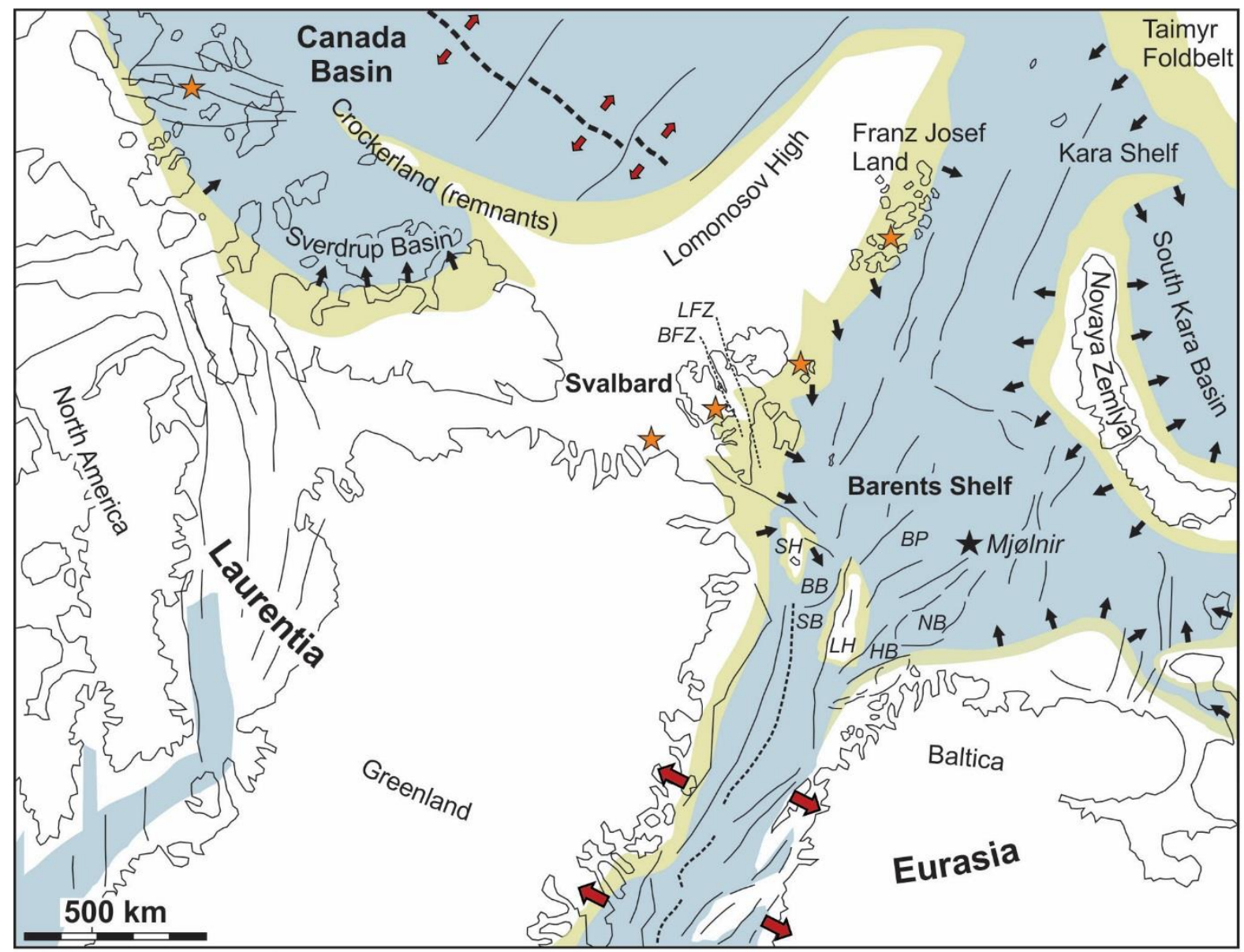

$\square$ Undifferentiated terrain $\square$ Shallow/marginal marine $\square$ Open marine shelf $\Rightarrow$ Migration direction $\Rightarrow$ Rifting/sea-floor spreading

Fig. 2. Palaeogeographic map showing the regional tectonic setting and palaeo-drainage in the Early Cretaceous. The reconstruction represents the end of the Hauterivian and beginning of the Barremian when the initial rifting in the Canada Basin had been replaced by rapid sea-floor spreading. Note that the Barents Shelf acted as the final sink for many of its bordering and uplifted terrains. Based on Torsvik et al. (2002), Golonka et al. (2003), and Basov et al. (2009). Red stars indicate areas influenced by igneous activity in the Early Cretaceous. The black star indicates the position of the Mjølnir Impact Crater (see text for more details) BB: Bjørnøya Basin, BP: Bjarmeland Platform, FP: Finnmark Platform, FSB: Fingerdjupet Subbasin, HB: Hammerfest Basin, LH: Loppa High, NB: Nordkapp Basin, SB: Sørvestsnaget Basin, SH: Stappen High, BFZ: Billefjorden Fault Zone, LFZ: Lomfjorden Fault Zone.

\subsection{Onshore lithostratigraphy and depositional system}

In Svalbard, the Adventdalen Group (Parker, 1967; Fig. 3) is subdivided into the Upper

Jurassic Agardhfjellet Formation (not considered herein), and the Lower Cretaceous Rurikfjellet,

Helvetiafjellet and Carolinefjellet formations, which together form an up to $2 \mathrm{~km}$ thick siliciclastic succession (Figs. 3 and 4). The lower Rurikfjellet Formation (Valanginian-Hauterivian/early

Barremian) is shale-dominated and represents deposition on an open marine shelf (Wimanfjellet 
Member in Figs. 3 and 5). Thick successions of gravity flow deposits occur locally in the Rurikfjellet Formation (Braathen et al., 2012; informally referred to as the Advenpynten member in Figs. 3, 5b and 6). The base of the formation is defined by a condensed glauconitic clay unit, the Myklegardfjellet Bed, which formed during maximum flooding of the shelf (Dypvik et al., 1992; Fig. 3). Recent studies have dated the Myklegardfjellet Bed to be of earliest Valanginian age indicating the presence of an uppermost Volgian to lower Ryazanian hiatus in the immediate underlying strata (Wierzbowski et al., 2011; Koevoets et al., 2016; Fig. 3). This unconformity may be the onshore equivalent to the similaraged Base Cretaceous Unconformity (BCU in Fig. 3; Lundin and Doré, 1997; Osmundsen and Ebbing, 2008) recorded in several offshore basins on the Norwegian Continental Shelf. The amount of siltstone and sandstone increases upwards in the Rurikfjellet Formation (the Kikutodden Member in Figs. 3, 4b $\& 5 \mathrm{~d})$, recording a gradual change from outer shelf to inner shelf and shoreface environments possibly in response to uplift in the north (Dypvik et al., 1991; Gjelberg and Steel, 1995). The base of the unconformably overlying Helvetiafjellet Formation (Barremian-early Aptian) is a regionally extensive subaerial unconformity of early Barremian age which formed during peak uplift in the north (Gjelberg and Steel, 1995, 2013; Maher, 2001; Figs. 3-6). The uplift, which is linked to the opening of the Canada Basin, resulted in a forced regression with sediment dispersal towards the SE (Gjelberg and Steel, 1995; Midtkandal and Nystuen, 2009). Above the basal boundary, the Helvetiafjellet Formation shows an overall transgressive development, and consists of a lower sandstone-dominated sheet-like unit deposited in a fluvial braidplain setting (the Festningen Member in Figs. 3, 4c and 6), and an upper heterolithic unit rich in thin coals and carbonaceous shales deposited in paralic environments (the Glitrefjellet Member in Figs. 3 and 6; Gjelberg and Steel, 1995; Midtkandal and Nystuen, 2009). At Kvalvågen, eastern Spitsbergen, the Glitrefjellet Member includes three regressively stacked deltas immediately above the fluvial sandstone sheet (Fig. 5e). The conformably overlying Carolinefjellet Formation (early Aptian-Albian) was grossly deposited in an open marine, storm-dominated shelf setting and consists of 


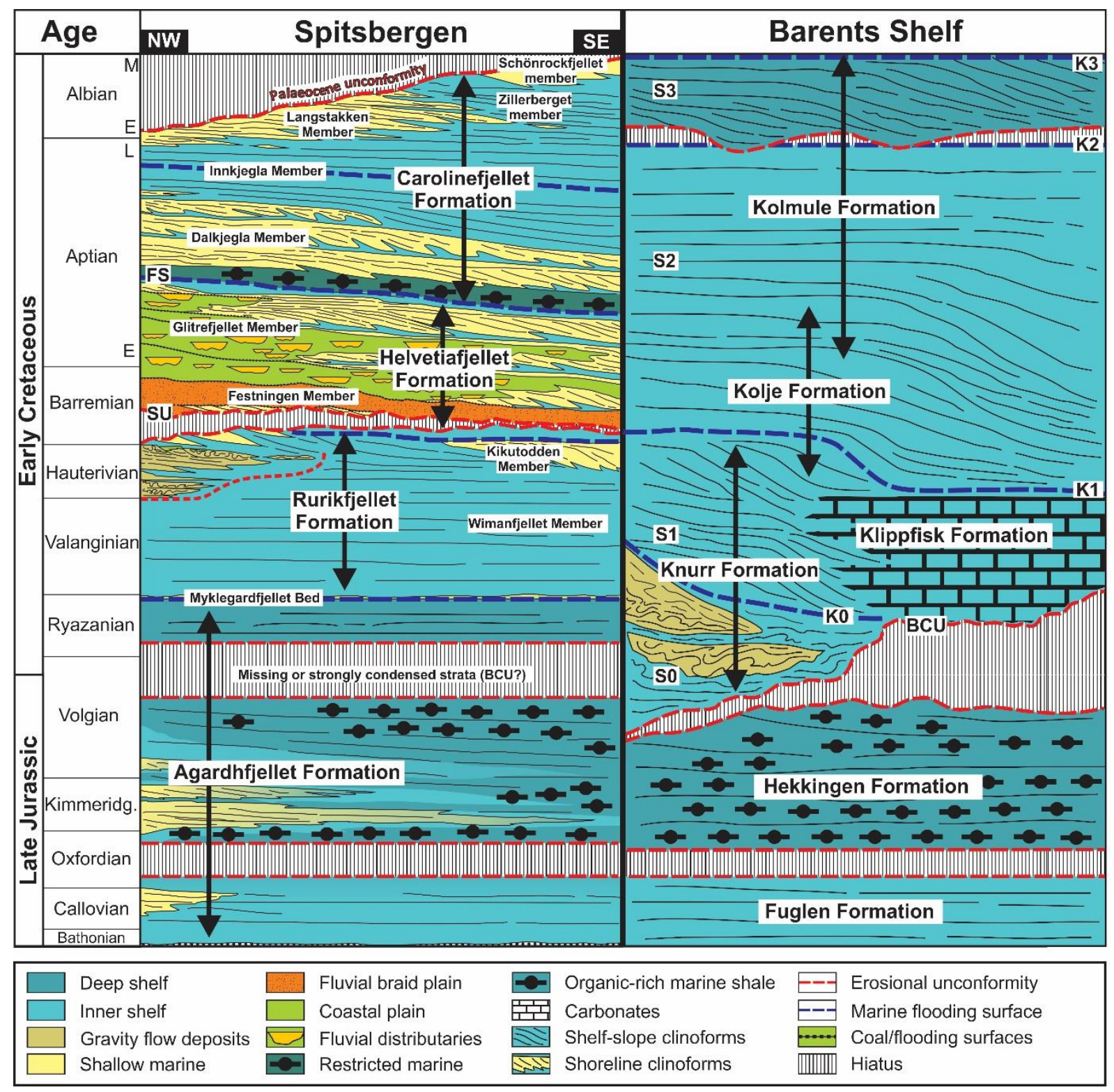

Fig. 3. Stratigraphic cross-section showing the regional development of the Upper Jurassic to Lower Cretaceous Adventdalen Group on Spitsbergen and the Barents Shelf. Onshore, the Myklegardfjellet Bed separates the Upper Jurassic from the Lower Cretaceous and corresponds to a maximum flooding surface. The underlying Berriasian hiatus probably corresponds to the Base Cretaceous Unconformity (BCU) in the offshore basins. To facilitate discussion, the third-order sequences on the Barents Shelf (SO-S3) have roughly been correlated to the lithostratigraphic units. The sequences are bounded by flooding surfaces (K0-K3) of regional extent. The crosssection integrates data compiled from Parker (1967), Nagy (1970), Steel and Worsley (1984), Dypvik et al. (1991), Gjelberg and Steel (1995, 2013), Midtkandal et al. (2007, 2008), Marin and Escalona (2014), Koevoets et al. (2016), Midtkandal et al., 2016, Vickers et al. (2016), and Grundvåg and Olaussen ((2017) No vertical scale intended. BCU: Base Cretaceous Unconformity, URU: Upper Regional Unconformity, SU: lower Barremian subaerial unconformity, FS: lower Aptian flooding surface.

alternating inner shelf sandstones and offshore mudstones (Nagy, 1970; Hurum et al., 2016; Figs. 36). The boundary between the Helvetiafjellet and Carolinefjellet formations has traditionally been 
described as interfingering (Gjelberg and Steel, 1995). However, the present study have demonstrated that in most outcrop sections in Spitsbergen, a c. 10-30 m thick black shale unit separate the two formations (FS in Figs. 4-6). The shale is dated to be of an early Aptian age and interpreted as a regional flooding event marking a return from paralic to open marine shelf environments (Figs. 4-6). Recent carbon isotope $(\delta 13 \mathrm{C})$ studies have also identified the early Aptian oceanic anoxic event (OAE1a) within the shale unit (Midtkandal et al., 2016; Vickers et al., 2016). 


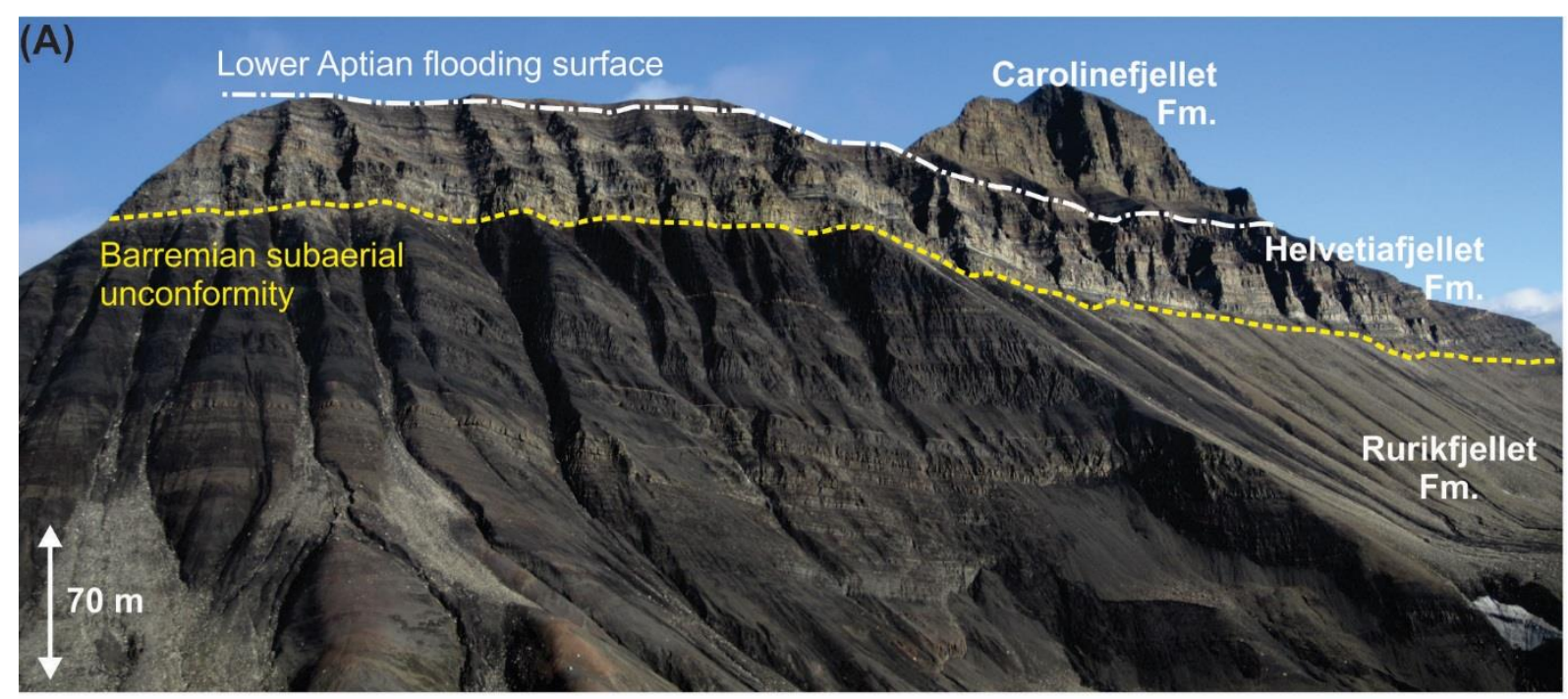

(B)

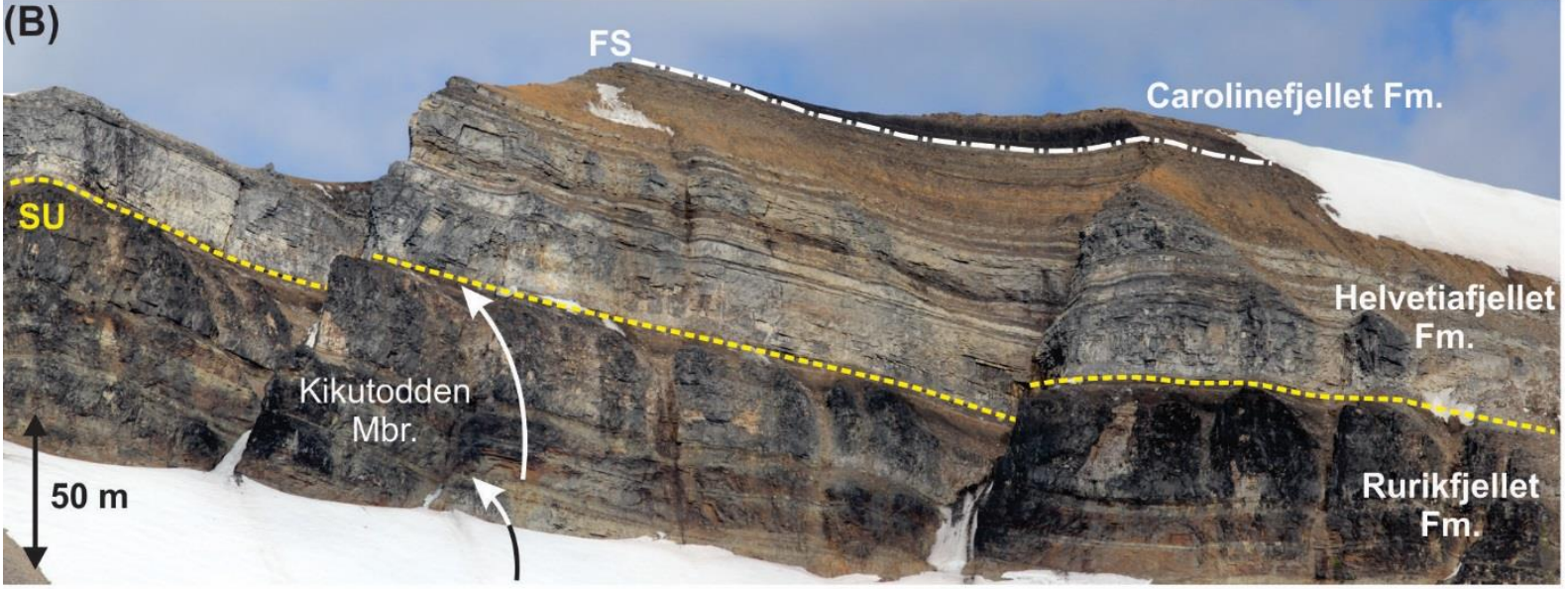

(C)

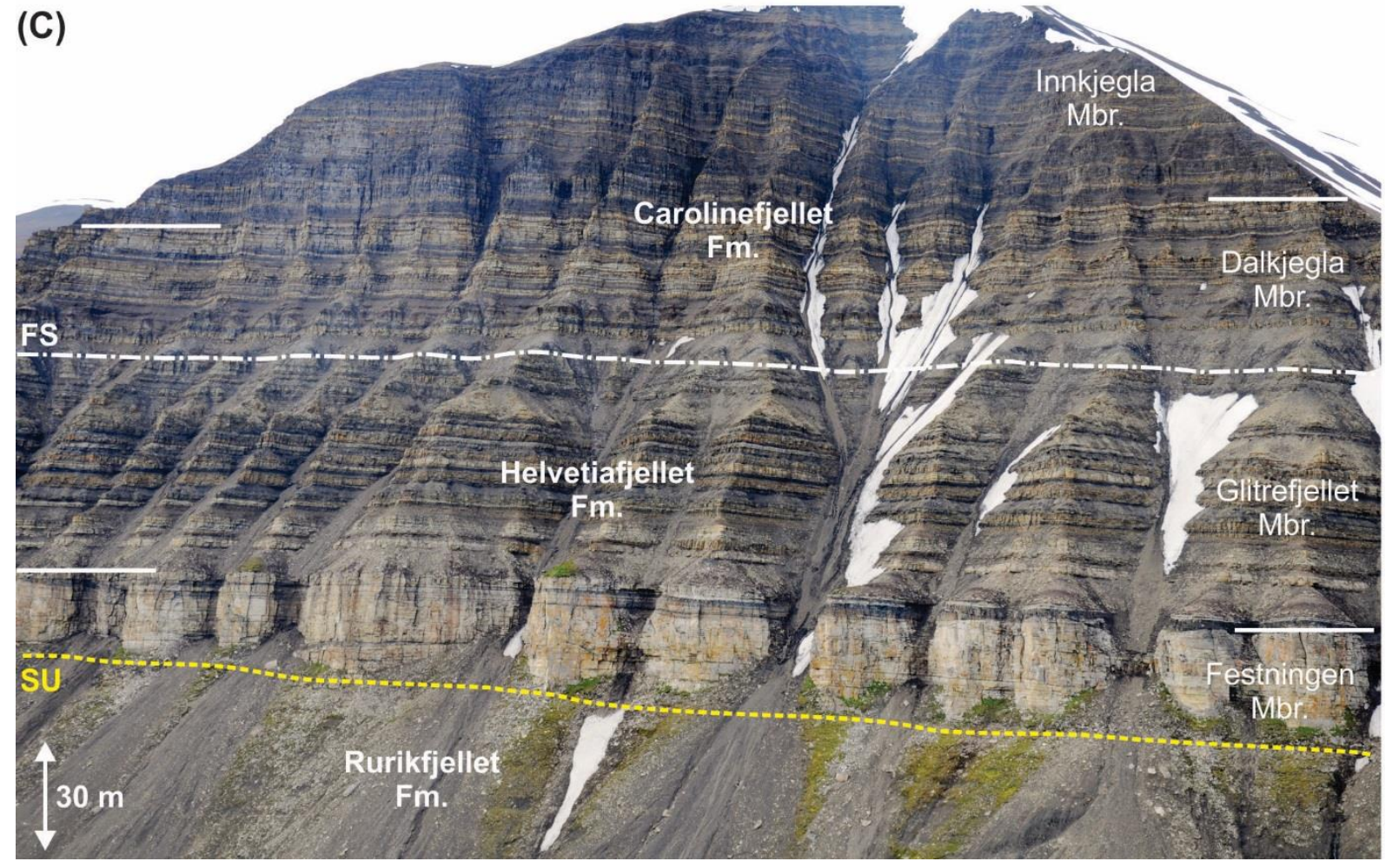


Fig. 4. (A) Picture showing the lithostratigraphic development at Louiseberget in south central Spitsbergen. A lower Barremian subaerial unconformity (annotated SU in the following pictures) and a lower Aptian flooding surface (annotated FS in the following pictures) separates the paralic Helvetifjellet Formation from the open marine shelf deposits of the Rurikfjellet and Carolinefjellet formations, respectively. Note that the Rurikfjellet Formation is shale-dominated. (B) Picture showing the Lower Cretaceous succession at Keilhaufjellet in the southernmost part of Spitsbergen. The upper Rurikfjellet Formation (Kikutodden Member) consists of sandstone-dominated, coarsening-upward parasequences (white arrows) at this location (see also Fig. 5d). (C) The Lower Cretaceous succession at Båtsmannen, eastern Spitsbergen. The member subdivision is easy to recognize. Note that both the Barremian subaerial unconformity and the lower Aptian flooding surface is present in all the outcrops and thus represent regional events. For location see Fig. 1b.

(A) Festningen

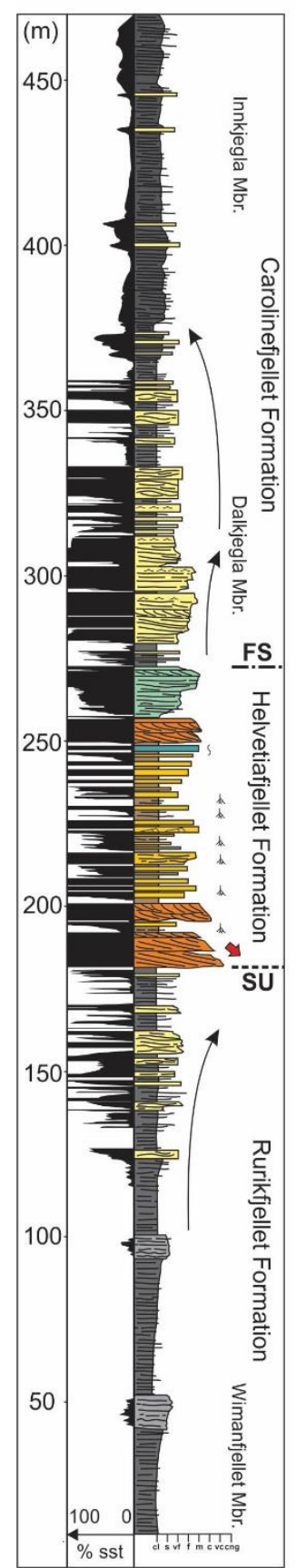

(B) Adventdalen Dh-5

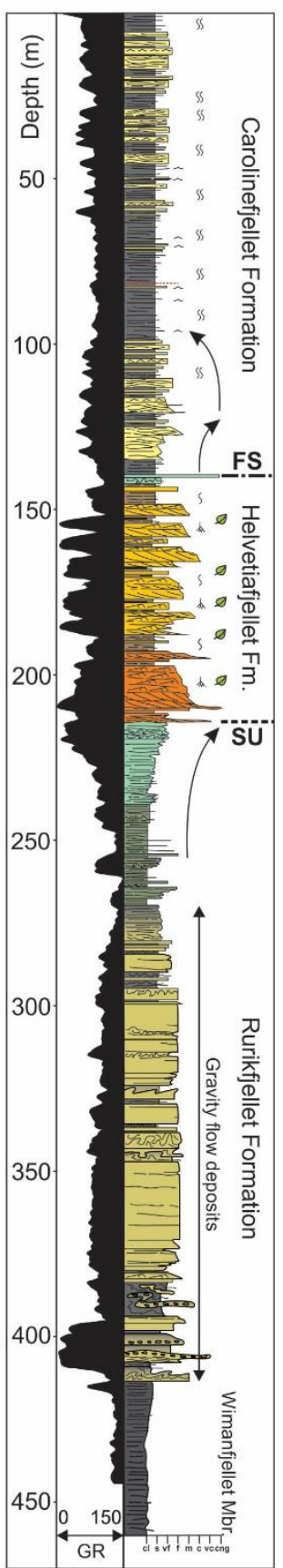

(C) Louiseberget

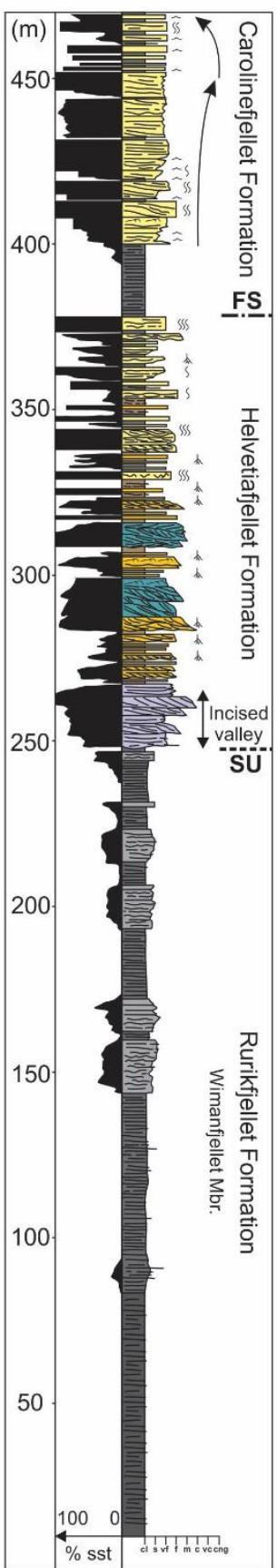

(D) Kvalvågen

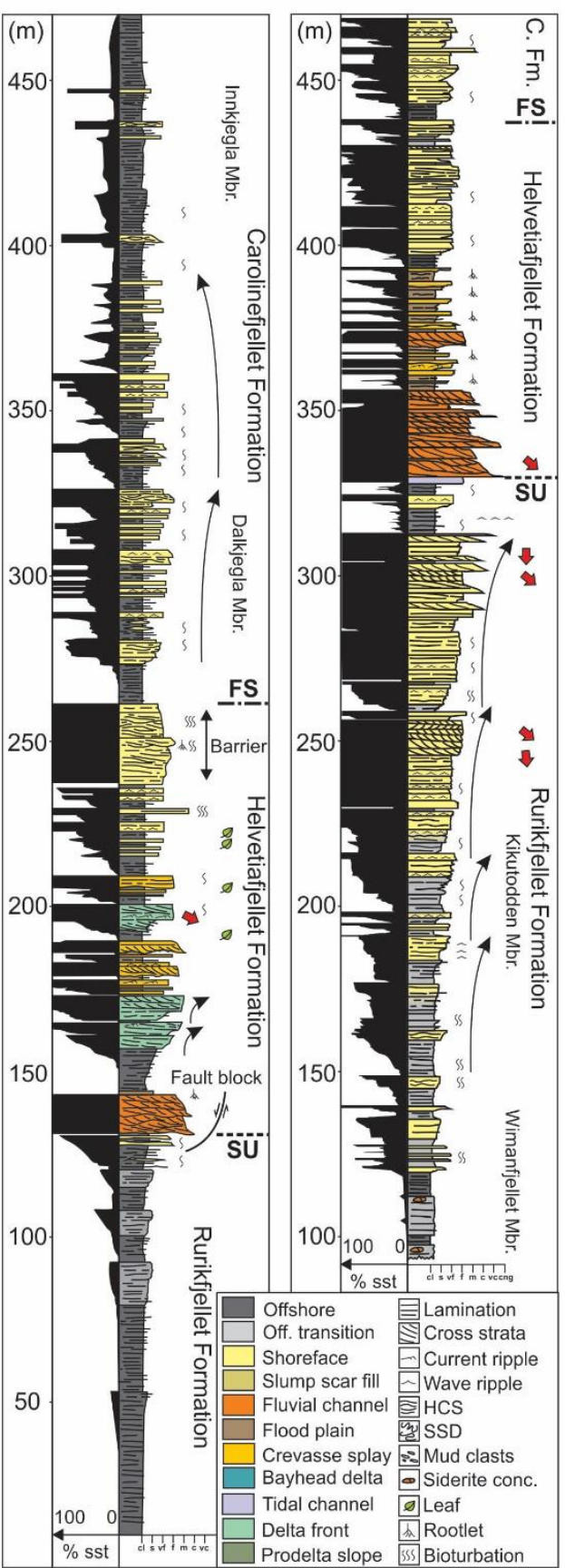

(E) Keilhaufjellet 
Fig. 5. Five vertical sections from Spitsbergen showing the lateral development of the Valanginian to lower Aptian depositional system from north to southeast. The sections are not stratigraphically correlated. Red arrows indicate general palaeo-flow directions measured on dune-scale crossstratification. SU: lower Barremian subaerial unconformity, FS: lower Aptian flooding surface, HCS: Hummocky cross-stratification, SSD: Soft-sediment deformation, GR: Gamma ray, Sst: Sandstone. Grain sizes: cl: clay, s: silt, vf: very fine sand, f: fine sand, m: medium sand, c: coarse sand, vc: very coarse sand, cng: conglomerate (granule and pebble size). For section location see Fig. $1 \mathrm{~b}$ and c.

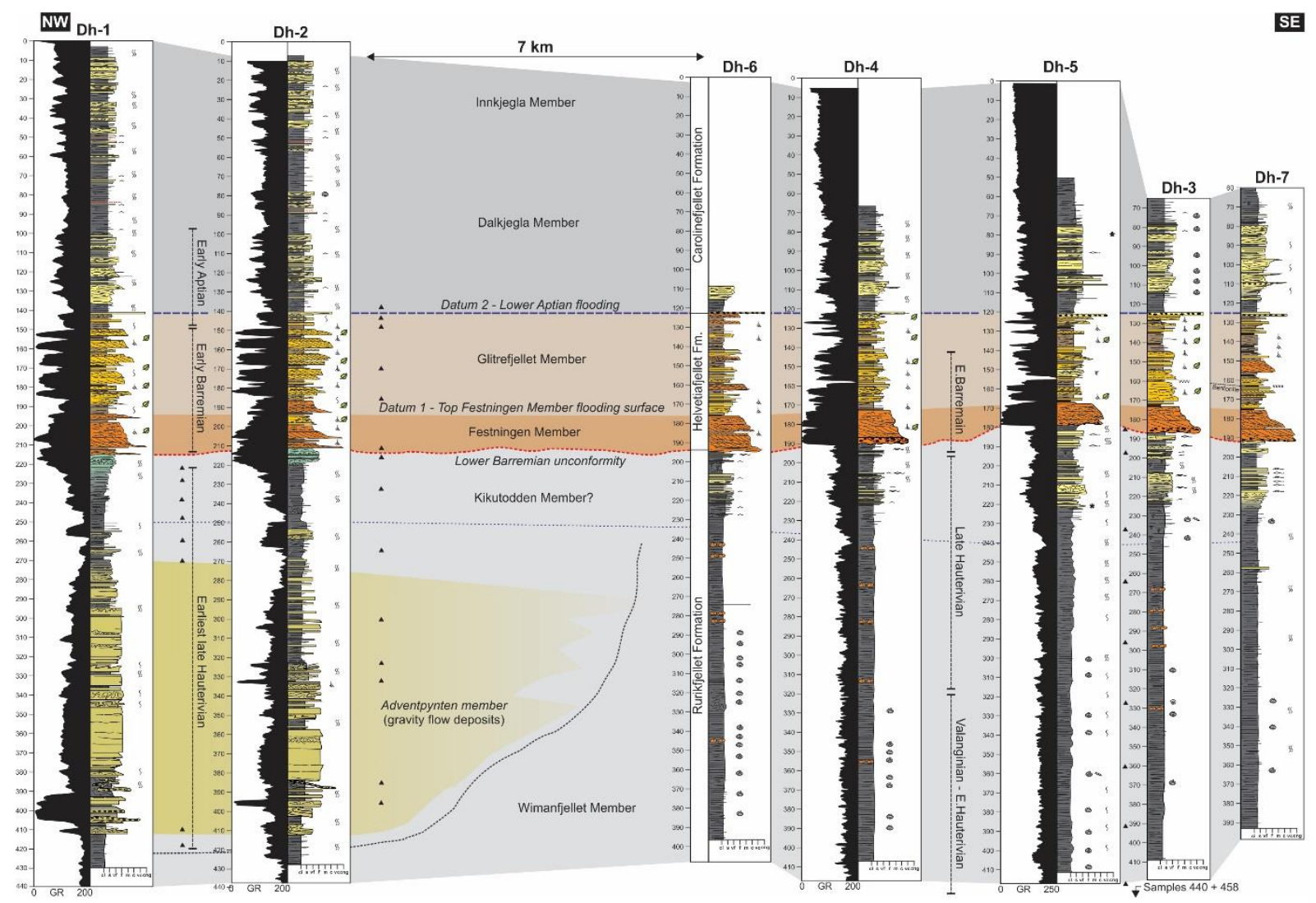

Fig. 6 (should be landscape in the printed version). Correlation panel linking the seven onshore wells in central Spitsbergen. The panel is corrected for structural dip and is flattened on the lower Aptian flooding surface separating the Helvetiafjellet and Carolinefjellet formations. The panel is oriented in a NW-SE direction and is therefore oriented parallel to the inferred SE-directed palaeo-shoreline migration direction. Gamma ray logs are included for wells Dh-1, Dh-2, Dh-4 and Dh-5. Note the presence of a thick succession of gravity flow deposits in wells Dh-1 and Dh-2, here informally referred to as the Adventpynten member. Note also the local thickness variation of the Festningen Member, indicating variable degrees of incision and possibly the presence of incised valleys

\subsection{Offshore lithostratigraphy and depositional system}

In the offshore basins, the Adventdalen Group encompass Valanginian to Cenomanian deposits (Fig. 3). For convenience, it will, age-vise, be referred to as Lower Cretaceous for the remaining part of this paper. The group shows major lateral changes in facies and thickness, and in combination with poor data resolution, long distance correlations across basins that formed under 
various tectonic regimes, and the lack of detailed age constraints, this has led to a confusing lithostratigraphic nomenclature (Figs. 3 and 7). Although the existing lithostratigraphic framework provides a good basis for mapping at local basin scale, it does not facilitate a detailed understanding of the regional depositional history and palaegeography. A more genetic approach is necessary, particularly when it comes to correlation of the onshore and offshore depositional systems.

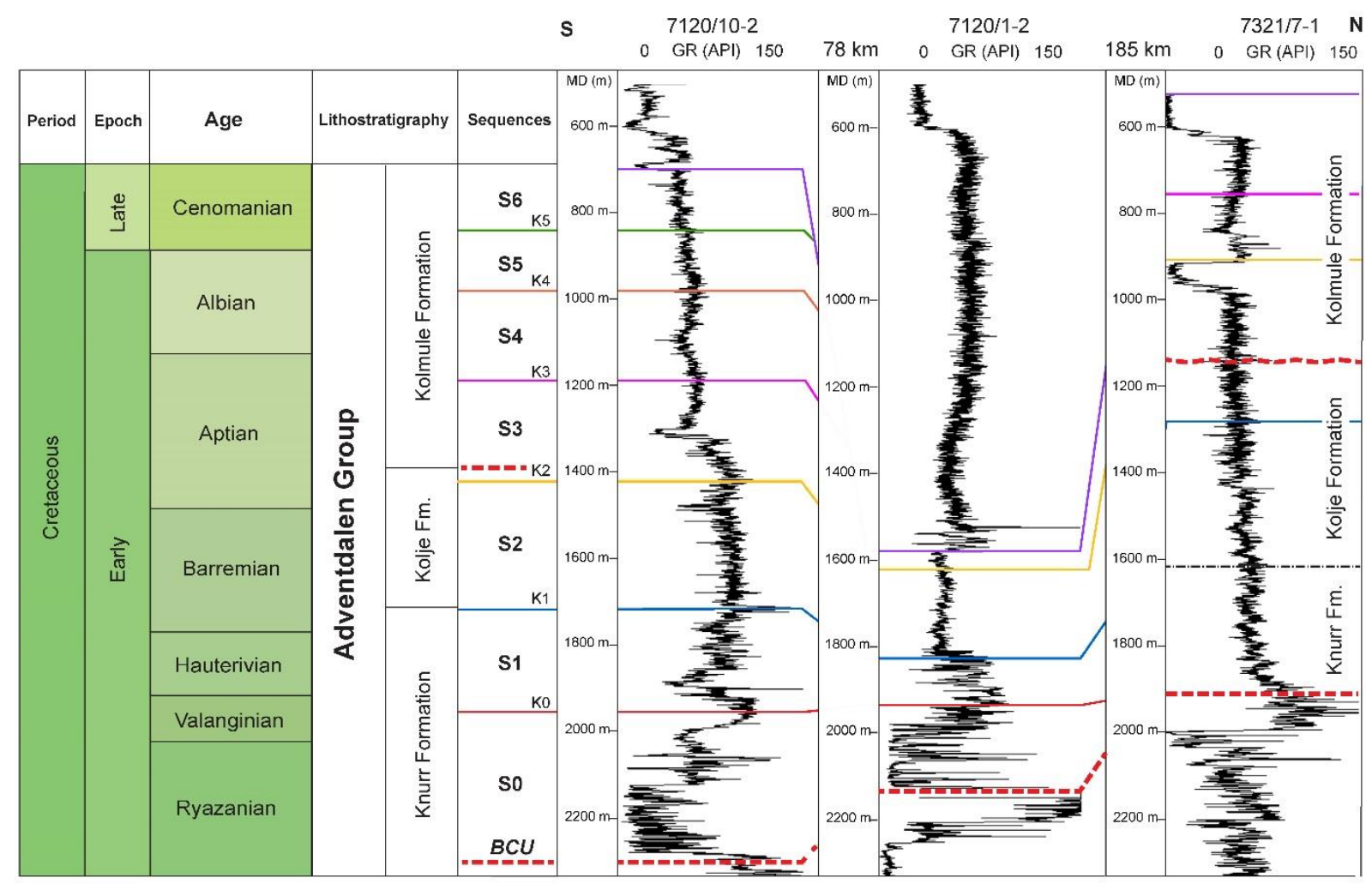

Fig. 7. North to south-oriented well panel from the Fingerdjupet Subbasin southward to the Hammerfest Basin showing the lateral correlation and distribution of the Lower Cretaceous seismic sequences. This study focus particularly on the S1-S3 interval. The sequence division is based on the recognition of regionally extensive flooding surfaces and biostratigraphic analyses. For location of the well transect, see Fig. 1b. BCU: Base Cretaceous Unconformity.

Offshore, the Adventdalen Group are generally confined by the Base Cretaceous Unconformity (BCU) and the Upper Regional Unconformity (URU; Fig. 3). In some places though, depending on degree of preservation, the Lower Cretaceous is overlain by thick Upper Cretaceous (the Nygrunnen Group) and Paleogene (the Sotbakken Group) strata (Worsley et al., 1988). The base of the Upper Cretaceous Nygrunnen Group is characterized by a Turonian-Santonian unconformity which 
separates it from the underlying Adventdalen Group. In some basins, the URU therefore truncates Upper Cretaceous or Paleogene rather than Lower Cretaceous strata (e.g. in the Hammerfest Basin; Solheim and Kristoffersen, 1984; Worsley et al., 1988). Within the Lower Cretaceous of the Barents Sea, seven sequences (S0-S6) each separated by flooding surfaces (K0-K5) have been identified by combining well data, biostratigraphy and seismic data (Marin and Escalona, 2014; Marin et al., 2016a; Figs. 3 and 7). Each sequence has a duration of 5-10 Ma, conforming to third-order sequences. A regional well correlation of the sequences are shown in Figure 7 (7120/10-2, 7120/1-2 and 7321/7-1), and regional well-tied, two-dimensional seismic lines are shown in Figure 8. This study only focus on S1-S3 (Figs. 3, 7 and 8), as S0 only occur as sedimentary wedges along the margin of the Hammerfest Basin (Marin et al., 2016a; Sattar et al., 2017), and the younger sequences S4-S6 typically show progradation from the NE towards the SW, the latter suggesting a regional change in source area and palaeo-drainage (Bugge et al., 2002; Marin et al., 2016a). The investigated sequences are roughly correlated to the lithostratigraphic units in Fig. 3, but for historical context a short review of the offshore lithostratigraphy follows.

Offshore, the Adventdalen Group is subdivided into the Klippfisk (late BerriasianHauterivian, locally early Barremian), Knurr (Valanginian-early Barremian), Kolje (early Barremianearly Aptian), and Kolmule formations(Aptian-middle Cennomanian, Worsley et al., 1988; Smelror et al., 1998; Fig. 3). Most of the offshore strata are shale-dominated and was apparently deposited in open-marine shelf environments (e.g. the Kolje Formation; Fig. 3). However, sandstones of shallow marine and fan delta origin occur locally in the Kolmule Formation in proximity to the Loppa High (e.g. the 7120/6-3S Juksa, 7220/10-1 Salina and 7120/2-3S Skalle wells; Fig. 1 for location). In addition, sandstone-dominated gravity-flow deposits are known from the Knurr Formation, typically occurring along basin-bounding faults (Seldal, 2005; Henriksen et al., 2011; Marin et al., 2016a; Sattar et al., 2017; Fig. 3). Condensed carbonates (i.e. glauconitic limestones and marls) deposited during a regional transgression occur locally on the platforms and highs, and is referred to as the Klippfisk Formation (Smelror et al. 1998; Fig. 3). The unit is in part equivalent to the Myklegardfjellet Bed on Spitsbergen (Dypvik et al., 1992; Fig. 3). In some areas, like the Bjarmeland Platform, the clinoforms 
described in this study downlap onto the top surface of the Klippfisk Formation (Århus et al., 1990;

Fig. 3). The basal boundary of the formation is defined by the BCU (Århus et al., 1990; Lundin and Doré, 1997; Osmundsen and Ebbing, 2008). The unconformity which spans from latest Volgian to earliest Valanginian in age is characterized by an abrupt decrease in gamma ray response and increased velocity upward from the underlying shale-dominated Upper Jurassic Hekkingen Formation (Fig. 3). Its formation mechanisms is poorly understood, but it may have formed in relation to regional uplift resulting in a relative sea-level lowstand (Faleide et al., 1993), or alternatively as the result of a tsunami triggered during formation of the Mjølnir Impact crater (Rokoengen et al., 2005; see Fig. 2 for crater location).
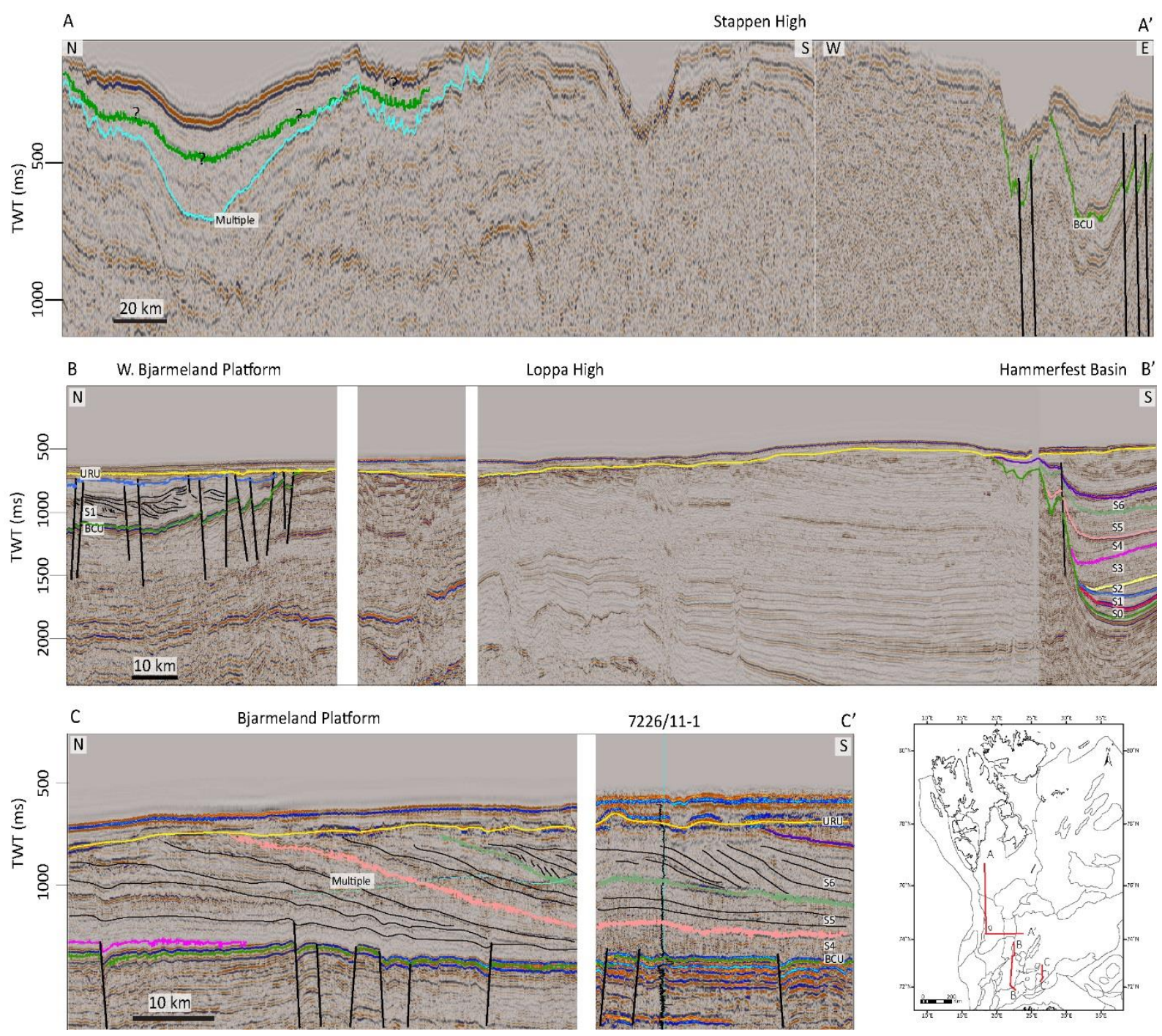

Fig. 8. Two-dimensional regional seismic profiles showing the interpreted sequence division and correlation. AA' is a composite profile going from the Edgeøya Platform south of Spitsbergen southward to the Stappen High 
turning east to the Hopenbanken Arch. The sequences are difficult to recognize in these northern areas due to the poor data quality and Cenozoic uplift and erosion. B-B' is an $\mathrm{N}-\mathrm{S}$-oriented profile going from the western Bjarmeland Platform southward across the Loppa High into the Hammerfest Basin where all the sequences are well preserved. Clinoforms occur in S2 and S3 on the Bjarmeland Platform. C-C' is a profile dip-oriented profile going from the Bjarmeland Platform southeastward into the Nordkapp Basin. The final shelf-break for the sequences investigated in this study $(\mathrm{S} 1-\mathrm{S} 3)$ is located in the northern part of the Nordkapp Basin. The inset map shows the location of the profiles, including the three shorter profiles shown in Fig. 9. BCU: Base Cretaceous Unconformity, URU: Upper Regional Unconformity.

\section{Data and methods}

\subsection{Onshore data}

The onshore data include logged sections from onshore wells (collective thickness of c. 2000 m; Fig. 6) and several outcrops (collective thickness $>3500 \mathrm{~m}$ ) together covering the entire extent of the Lower Cretaceous outcrop belt, including the southernmost outcrop section in Sørkapp Land (Keilhaufjellet section in Fig. 1b) and the inferred most proximal and northernmost section north of Isfjorden (Bohemanflya and Ramfjellet sections in Fig. 1c). Palaeocurrent data were obtained in all the visited outcrops and from previous publications (e.g. Gjelberg and Steel, 1995; Midtkandal and Nystuen, 2009). In addition, the gamma-ray log from three exploration wells (7815/10-1 Colesbukta, 7816/12-1 Reindalspasset, and 7815/3-1 Ishøgda) have aided in regional correlations between areas lacking good outcrops (Fig. 1c for location).

\subsection{Offshore data}

Two- and three-dimensional seismic and well data were provided by the Norwegian Petrobank database. The seismic data covers an area of $100000 \mathrm{~km}^{2}$ (Fig. 1c). The quality of the seismic is variable with general frequencies between 10 and $50 \mathrm{~Hz}$; multiples occur in some areas (Fig. 8). Vertical seismic resolution is in the order of 20-30 m. The seismic quality and resolution restrict interpretation in some areas, and low-relief clinoforms $(<100 \mathrm{~m})$, for example, can only be identified in the frequency range of $27-50 \mathrm{~Hz}$. The third-order sequence-bounding flooding surfaces were defined on the basis of the gamma-ray well logs (Fig. 7) in combination with reflector terminations (Fig. 8) according to the nomenclature of Mitchum et al. (1977). The trajectory analysis followed the 
principles outlined by Helland-Hansen and Hampson (2009) and was performed on flattened seismic cross-sections oriented close to the perpendicular direction of clinoform progradation. The lines used for this purpose were flattened on the $\mathrm{BCU}$, or on regional flooding surfaces in the topset or bottomset segment of the investigated clinforms (Fig. 9). The BCU is considered here to lack any significant relief on the platform areas because a parallel continuous reflector interpreted to be a flooding surface (Surface K0; Fig. 3) is generally observed to occur immediately above it. An exception is along the margin of the Hammerfest Basin were the sedimentary wedges of S0 occur and separate the BCU from the overlying K0 flooding surface.

Only the three most representative wells used for the definition and correlation of the seismic sequences are shown herein (7120/10-2, 7120/1-2 and 7321/7-1; Fig. 7), see Marin and Escalona (2014) and Marin et al. (2016a) for a complete well list. Because most of the exploration wells with Lower Cretaceous core data specifically targeted submarine fans of the Knurr Formation (e.g. 7019/1$1,7120 / 1-2,7120 / 10-2,7122 / 2-1$ and 7321/7-1), no exploration wells have to date have fully cored any of the clinoform packages. However, some shallow stratigraphic wells penetrate parts of the clinoform sequences; well 7231/1-U-1 penetrate what is inferred to be the toeset of S2 in the Nordkapp Basin, whereas well 7231/4-U-1 penetrate parts of the topset of the same sequence. In the northernmost part of the Bjørnøya Basin, well 7320/3-U-1 probably penetrates S1 where a $30 \mathrm{~m}$ thick coarsening upwards mudstone-dominated unit of early Barremian age sharply overlies condensed carbonates of the Klippfisk Formation (Århus et al., 1990). Core descriptions of the published shallow stratigraphic wells 7230/5-U-9, 7231/1-U-1, 7320/3-U-1, 7430/10-U-1, and 7425/9-U-1 have been integrated in this study (Århus et al., 1990; Århus, 1991a; Smelror et al., 1998; Bugge et al., 2002; Langrock et al., 2003).

\subsection{Biostratigraphic data}

Palynological analysis (dinoflagellate cysts; dinocyst) were carried out on altogether 101 sediment samples. From Svalbard, 72 samples were collected in both outcrops sections (Bohemanflya, Keilhaufjellet, Baugen, Båtsmannen, Louiseberget, Ullaberget and Schönrockfjellet; Fig. 1b for location) and drill cores (wells Dh-1: eight samples; Dh-2: 14 samples; Dh-5: 11 samples). From the 
Barents Sea samples for palynological analysis were collected from cored intervals of five wells (7019/1-1, 7120/1-2, 7120/2-2, 7121/5-1 and 7121/5-2; Fig. 1c for location; Fig. 7 for well correlation of the three first wells). Palynological slides were prepared at the Geological Survey of Denmark and Greenland (GEUS) by conventional processing techniques used for palynological preparation as described by Nøhr-Hansen (2012).

Additionally, 20 palynological slides from wells 7121/5-1 and 7121/5-2 were analyzed. These slides were prepared from ditch cutting (DC) and sidewall core (SWC) samples. The slides from these two wells were prepared by Statoil and were borrowed from the Norwegian Petroleum Directorate (NPD). Slides have been scanned in order to identify key species. For the uppermost Hauterivian to Albian strata, we have applied the dinocyst zonation of Nøhr-Hansen (1993) established for NorthEast Greenland. Most of the analyzed samples contained age-diagnostic dinocysts.

In the Olga Basin, shallow vibrocores containing Lower Cretaceous deposits have been described and biostratigraphically dated by Antonsen et al. (1991). This data have been used for a preliminary age assignment of the sequences in the northeastern part of the study area.

\section{Onshore depositional trends}

The facies types in the onshore succession are thoroughly documented in previous papers (e.g. Edwards, 1976; Mørk, 1978; Nemec et al., 1988; Dypvik et al., 1991; Nemec, 1992, Gjelberg and Steel, 1995; Midtkandal et al., 2007; Midtkandal and Nystuen 2009; Grundvåg and Olaussen, 2017) and will not be reiterated in detail here. However, the facies development and the spatial distribution of individual depositional elements going vertically from the base of the Rurikfjellet Formation and upwards through the Helvetiafjellet and Carolinefjellet formations are briefly summarized as basis for a regional synthesis of the basin fill history and its controls. The vertical facies development at three different locations are summarized in Fig. 4, and generalized sedimentary logs is shown in Figs. 5 and 6.

\subsection{Depositional trends of the Rurikfjellet Formation}


The basal unit of the Rurikfjellet Formation, the Myklegardfjellet Bed, consists of an up to 10 $m$ thick plastic clay unit rich in glauconite deposited during maximum flooding of the shelf. Recent stratigraphic investigations indicate the presence of a significant hiatus in the strata immediately below the Myklegardfjellet Bed (Wierzbowski et al., 2011; Koevoets et al., 2016). A similar setting is seen offshore where the base of the age- and lateral-equivalent to the Myklegardfjellet Bed, the Klippfisk Formation, is defined by the BCU (Århus et al., 1990). Although some Upper Jurassic sandstone wedges may have a northern source terrane, the Myklegardfjellet marks the onset of a tectonically controlled regional regression with sediments being derived from uplifted terranes north of Svalbard. The lower Rurikfjellet Formation, the Wimanfjellet Member, consists of mudstones deposited in an outer shelf setting (Figs. 3-5 and 9a). The mudstones grade upwards into siltstones and very-fine grained sandstones deposited in an offshore transition to lower shoreface setting (Fig. 3; Dypvik et al., 1991). In the north central part of Spitsbergen the siltstones and sandstones form shallowing upwards parasequences (sensu Van Wagoner et al., 1990; Figs. 3, 5a, 6 and 9b). Individual parasequences are $10-50 \mathrm{~m}$ thick, and stacked units are separated by flooding surfaces. The source area for this system must have been located N-NW of the present day outcrop belt as the parasequences are not that welldeveloped in eastern, south-central, or southeastern Spitsbergen (Figs. 3 and 5), reflecting proximaldistal trends and a south to mainly southeastward prograding shoreline. In southernmost Spitsbergen, coarser-grained and more quartz-rich parasequences which generally show progradation towards the S-SE occur (the Kikutodden Member; Figs. 3-5). Individual units are up to $50 \mathrm{~m}$ thick and stack to form a 150 m thick sandstone-dominated package (Edwards, 1976; Mørk, 1978; Grundvåg and Olaussen, 2017.; Figs. 4b \& 5e). The parasequences are interpreted to represent successively southward-progradig shoreline tongues. The lack of backshore and coastal plain deposits in any of the parasequences indicate high rates of sediment accumulation relative to the rates of relative sea-level change. The rapid basinward accretion resulted in low-angle facies lines and limited accommodation space for such deposits to accumulate. Alternatively, all backshore deposits got eroded during the intervening transgressions, or the sea level at all times were too deep. In this regard, each parasequence may represent an infralittoral prograding wedge (sensu Hernández-Molina et al. 2000) that formed a subaqueous platform in front of the actual shoreline. It is suggested here that these 
parasequences had their source area to the west as similar units are not present north of Fotografryggen in Wedel Jarlsberg Land (the Fo section in Fig. 1). A potential source area could be Greenland, which was located much closer to the western margin of the Barents Shelf and Svalbard in the Early Cretaceous than at present (Fig. 2). In most studied outcrops, a 5-30 m thick marine shale unit occur on top of the uppermost sand-rich parasequence. This suggests an early Barremian regional flooding event (possibly corresponding to surface K1 offshore; Fig. 3) prior to the formation of the subaerial unconformity at the base of the overlying Helvetiafjellet Formation (Fig. 3). 

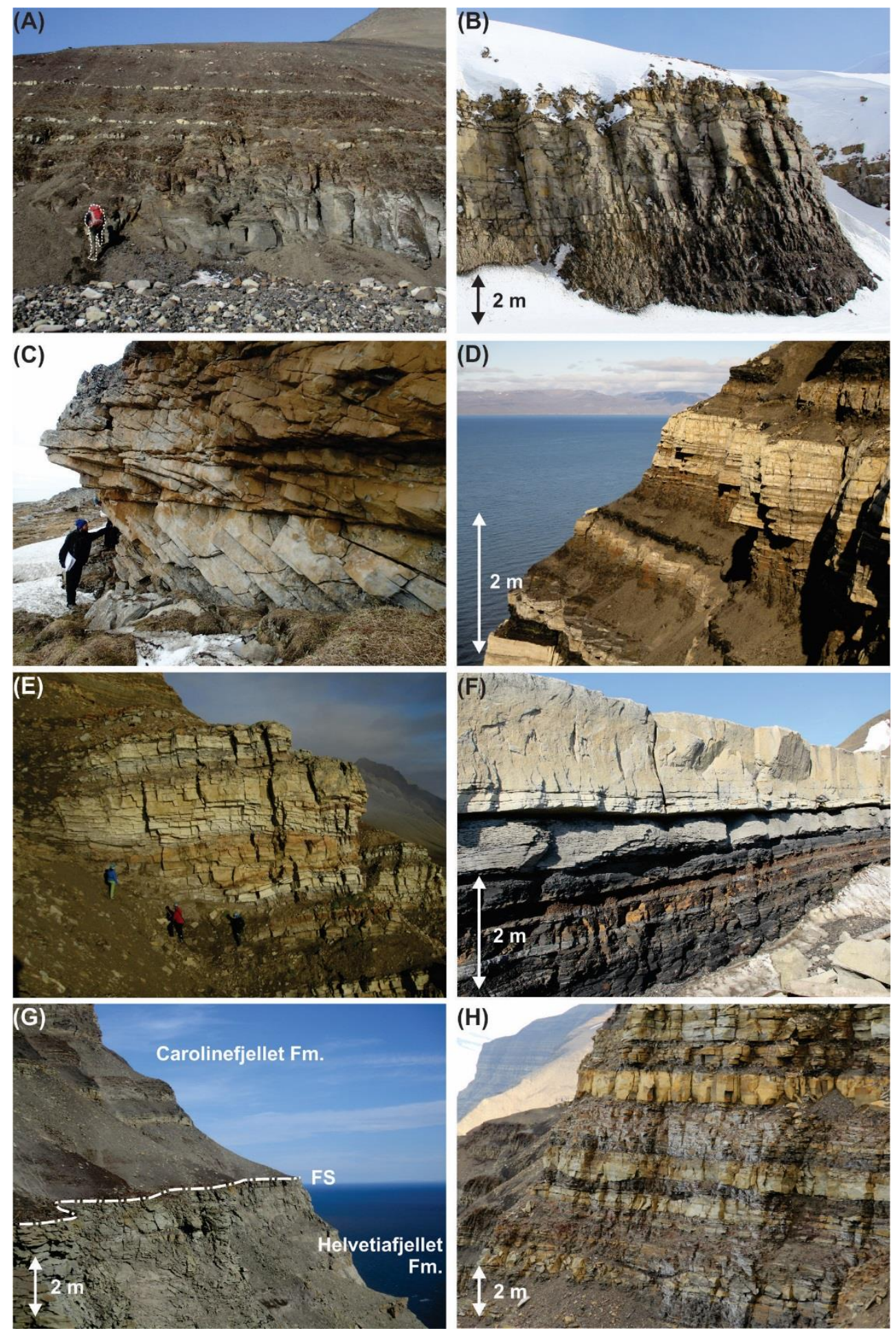

Fig. 9. (A) Typical expression of the shale-dominated Wimanfjellet Member of the Rurikfjellet Formation (location Ba, Fig. 1b). Person for scale $(180 \mathrm{~cm})(B)$ Coarsening- and shoaling upward lower shoreface parasequence in the Kikutodden Member of the Rurikfjellet Formation (location A, Fig. 1b). (C) Meter-scale stratification in fluvial braidplain deposits in the Festningen Member of the lower Helvetiafjellet Formation (person for scale: c. $185 \mathrm{~cm}$, location A, Fig. 1b). The upper Helvetiafjellet Formation consists of various paralic deposits and include (D) flood plain and crevasse splay (location Is, Fig. 1b), (E) tidal channel (persons for scale: c. $170 \mathrm{~cm}$, location U, Fig. 1b), and (F) mouth bar deposits (location Kv, Fig. 1b). (G) The formation is capped by a lower Aptian flooding surface (annotated FS) marking a return from paralic to open marine shelf deposition in the Carolinefjellet Formation (location Ba, Fig. 1b). (H) The sandstone-dominated part of the Dalkjegla 
Member in the lower Carolinfjellet Formation consists of various storm deposits that accumulated in an offshore transition to lower shoreface setting on a shallow, open-marine shelf (location Bå, Fig. 1b).

\subsection{Age of the Rurikfjellet Formation}

Foraminiferal fauna reported from the basal Myklegardfjellet Bed suggest predominantly an early Valanginian age for this unit, but may also include the uppermost Ryazanian (Dypvik et al., 1992; Koevoets et al., 2016). The depositional break reported in the Upper Jurassic Agardhfjellet Formation underlying the Myklegardfjellet Bed spans the uppermost Volgian and lower Ryazanian (Wierzbowski et al., 2011; Koevoets et al., 2016), and may thus correlate to the BCU offshore (Fig. 3).

The dinocyst from the Rurikfjellet Formation were analysed in three onshore wells (Dh-1, Dh2 and Dh-5; Fig. 6) and in samples from the Bohemanflya and Ullaberget outcrop sections. The preservation of dinocysts in the Rurikfjellet Formation is moderate to poor and the assemblages are of low diversity. Based on the presence of the two most common dinocyst markers Endoscrinium hauterivianum and Nelchinopsis kostromiensis the Rurikfjellet Formation is dated as late Valanginian to late Hauterivian (Fig. 10). Our result confirms the previous age assessment of Århus (1992). Based on the presence of Pseudoceratium anaphrissum specimens in the Dh-5 well and in the Bohemanflya outcrop section, as well as Dingodinium cerviculum, Muderongia tetracantha, Oligosphaeridium complex, questionable Pseudoceratium anaphrissum and Subtilisphaera perlucida specimens in the Ullaberget outcrop section, the uppermost part of the Rurikfjellet Formation is tentatively assigned an early Barremian age (Subzone I (2); Figs. 3 and 10). A Barremian age for the uppermost few meters of the formation have previously been suggested by Grøsfjeld (1992).

\subsection{Depositional trends of the Helvetiafjellet Formation}

The base of the overall transgressive Helvetiafjellet Formation is defined by a regionallyextensive subaerial unconformity that by variable amounts cut down into the underlying strata (Nemec, 1992; Gjelberg and Steel, 1995, 2013; Midtkandal et al., 2008; Figs. 3-6). For large parts of the outcrop belt, the unconformity separates underlying marine shales from fluvial sandstones, and its presence is a spectacular proof of forced regression as it represent a major sediment bypass surface (Steel et al., 2000). The lower Helvetiafjellet Formation, the Festningen Member (Figs. 3 and 6), consists of fine- to very coarse-grained pebbly sandstones and conglomerates with abundant cross- 
stratification indicating deposition in a low-gradient braid-plain setting (Nemec, 1992; Gjelberg and Steel, 1995; Figs. 5, 6 and 9c). The rivers were generally transporting sediments in a southeastward direction (Gjelberg and Steel, 1995; Midtkandal and Nystuen, 2009). However, in Kong Karls Land, eastern Svalbard, the fluvial system are confined to topographic lows between SW-NE-trending anticlines and a southwestward palaeo-drainage is evident (Olaussen et al., pers. Comm., 2016). Local and abrupt thickness-variations indicate that the 


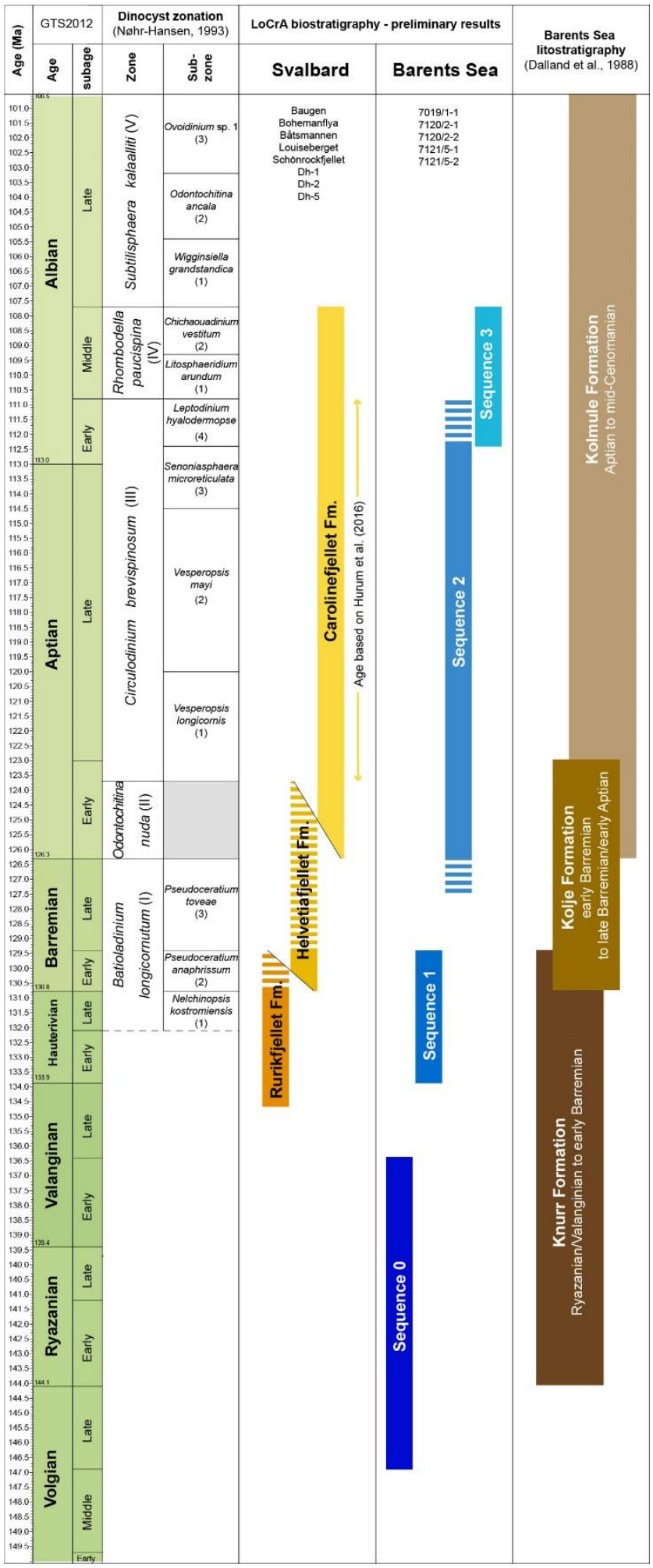

Fig. 10. Ages for the Lower Cretaceous succession of Spitsbergen and four of the sequences (S0-S3) sensu Marin et al. (in press.) of the SW Barents Shelf referred to the dinocyst zonation of Nøhr-Hansen (1993). Dashed columns represent tentative ages. Note that ages for Subzones I 1 and I 2 are updated. Ages for the upper part of the Carolinefjellet Formation is based on Hurum et al. (2016), and ages for the lithostratigraphic units of the Barents Sea is based on Dalland et al. (1988). 
lower part of the Festningen Member was deposited in wide, and partly coalescing river valleys that formed during shelf exposure in the early Barremian (Nemec, 1992; Midtkandal and Nystuen, 2009; Fig. 6). In some of the incised river valleys, higher frequency relative sea-level fluctuations driven by multiple episodes and variable rates of uplift, promoted intra-valley incisions and the development of bay head deltas and estuaries as evident at the Louiseberget and Ullaberget localities (Gjelberg and Steel, 1995; Midtkandal et al., 2008; Fig. 5c). The top of the braid-plain unit represent an expansion surface which marks the change from a low-accommodation setting controlled by the incised valley topography to a high-accommodation setting characterized by both increasing lateral and vertical accommodation (Figs. 3 and 6). In many areas, particularly in eastern Spitsbergen, this surface also represent a marine flooding surface where overlying deltas downlap onto it (Nemec et al., 1988; Steel et al., 2000; Onderdonk and Midtkandal, 2010; Fig. 5d). The upper Helvetiafjellet Formation, the Glitrefjellet Member, consists of variable amounts of alternating mudstones, sandstones and thin coals deposited in continental to paralic settings, including flood plain, crevasse splay, tidally influenced distributary channels, and mouth bar to interdistributary bay environments (Nemec, 1992; Gjelberg and Steel, 1995; Midtkandal et al., 2007; Figs. 5, 6 and 9d-f). In areas that was still affected by the incised valley-topography, typically in central Spitsbergen, large tidal-dominated estuaries formed (e.g. Gjelberg and Steel, 1995; Midtkandal and Nystuen, 2009; Figs. 5c and 9e). The marine influence generally increases upwards, and the upper part of the unit include sediments deposited in waveinfluenced delta front and barrier environments (Nemec et al., 1988; Nemec, 1992; Fig. 5d). The boundary to the overlying Carolinefjellet Formation is marked by an abrupt upward-deepening of facies from delta front or barrier sandstones to offshore shale (Fig. 9g). The shale is typically 10-30 m

thick and represent a marine flooding surface of regional extent (Figs. 3, 4, 5 and 6). Locally, a transgressive lag formed by wave-ravinement is also present at the boundary (Fig. 6).

\subsection{Age of the Helvetiafjellet Formation}

Within the Helvetiafjellet Formation, biostratigraphical analysis were carried out on five samples from well Dh-2 and on 12 samples from the Ullaberget outcrop section. The dinocyst preservation is very poor and the diversity is low, and the samples are dominated by terrestrially- 
derived particles (i.e. wood, pollen, spores and plant membranes), in line with the continental to paralic and restricted marine depositional setting of the formation (Grøsfjeld, 1992; Midtkandal et al., 2016). In well Dh-2, the presence of Odontochitina nuda and $P$. anaphrissum in the lower and middle part of the formation indicates a possible early Barremian age (Subzone I (2); Fig. 10). In the samples from the Ullaberget outcrops section, the co-occurrence of Circulodinium aff. attadalicum sensu NøhrHansen 1993 (ranges from early Barremian to early Aptian, Nøhr-Hansen, 1993), Muderongia australis (ranges from Hauterivian to early Barremian; Århus et al., 1990), Pseudoceratium anaphrissum and Stanfordella fastigiata (ranges from early Hauterivian to earliest late Barremian; Nøhr-Hansen 1993) supports an early Barremian age for the Helvetiafjellet Formation. Our data confirms dinocyst-derived age estimates by previous studies (Grøsfjeld, 1992) and those recently provided by Midtkandal et al. (2016) and Śliwińska et al. (2016). The age is however slightly older than the U-Pb dating $(123.3 \pm 0.2 \mathrm{Ma})$ performed on a bentonite in the middle of the formation in central Spitsbergen by Corfu et al. (2013). However, an early Aptian age may be suggested for the uppermost part of the formation based on the presence of Odontochitina nuda and Pseudoceratium cf. retusum (Nøhr-Hansen, 1993; Fig. 10). .

The dinocyst assemblage from the Helvetiafjellet Formation also yields a significant amount of taxa characterized by a variety of older ranges: Endoscrinium hauterivianum (range: early to earliest late Hauterivian), Nelchinopsis kostromiensis (range: Valanginian to Hauterivian or earliest Barremian), Tubotuberella sp. (resembles Jurassic species) and Tubotuberella apatela (range: Kimmeridgian to earliest Valanginian). The presence of these species indicates major reworking of older strata and is consistent with uplift and erosion of the northwestern margin of the Barents Shelf in the Barremian.

\subsection{Depositional trends of the Carolinefjellet Formation}

The lowermost part of the Carolinefjellet Formation, the Dalkjegla Member (Fig. 3), consists of the above-mentioned 10-30 m thick shale package deposited in a restricted to open marine shelf setting during marine flooding of the coastal plain of the underlying Helvetiafjellet Formation (Figs. 4, 5, and 6; Midtkandal et al., 2016; Vickers et al., 2016). The shale grade upwards into siltstones and very fine-grained sandstones arranged into a heterolithic coarsening and shoaling upwards unit up to 
$15 \mathrm{~m}$ thick (Figs. 5 and 6). The succeeding part of the Dalkjegla Member forms an up to $100 \mathrm{~m}$ sandstone-dominated succession that can be traced all across the outcrop belt (Nagy, 1970; Figs. 4, 5 and 6). Internally, this succession contains vertically stacked and commonly amalgamated coarseningupward parasequences (sensu Van Wagoner et al., 1990) representing offshore transition to lower shoreface environments of shoreline tongues that successively built out on to the shallow shelf (Fig. 5). The predominance of hummocky cross-stratified sandstones (Fig. 9h) and the marine trace-fossil assemblage (mixed Skolithos and Cruziana Ichnofacies) suggests an open-marine storm-dominated shelf (Fig. 5; Nagy, 1970; Maher et al., 2004). Locally, in west and north central Spitsbergen (the Festningen and Ramfjellet outcrop sections, Fig. 1c), medium to coarse-grained trough cross-stratified sandstones occur. These deposits represent upper shoreface environments and thus indicate proximaldistal trends and the possible presence of a shoreline N-NW of the present day outcrop belt (Maher et al., 2004). In the upper half of the Dalkjegla Member there is an overall retrogradational stacking trend; parasequences gradually thins and becomes more heterolithic upwards toward the overlying shale-dominated Innkjegla Member (Figs. 3, 5a, 5d, and 6; Nagy, 1970). The latter unit, which is several hundreds of meters thick, represent deposition in a slightly deeper shelf setting (Fig. 5).

\subsection{Age of the Carolinefjellet Formation}

The regionally-extensive shale package at the base of the Carolinefjellet Formation (biostratigraphically studied at the Baugen, Båtsmannen, Keilhaufjellet and Louiseberget outcrop sections and the Dh-2 well, Fig. 1c) is of earliest Aptian age (dinocyst Zone II of Nøhr-Hansen, 1993; Fig. 10). Samples from the Keilhaufjellet outcrop section (fig. 1c for location) yielded no datable palynomorphs due to its proximity to the Paleogene fold-and-thrust belt. The two most characteristic dinocysts in the other investigated outcrop sections are Pseudoceratium cf. retusum (sensu NøhrHansen, 1993) and Odontochitina nuda. In the Dh-2 well, the dinocyst assemblage yields additionally Subtilisphaera perlucida and Muderongia pariata. Based on ammonites, the Dalkjegla Member has previously been dated to Aptian, whereas the transitionally overlying Innkjegla Member was dated late Aptian to early Albian (Nagy, 1970). 
The two youngest units of the Carolinefjellet Formation, the Zillerberget and Schönrockfjellet members (Fig. 3), are of middle Albian age (Fig. 10). The dinocyst analysis of the Zillerberget member performed by Århus (1991b) were recently revised in Hurum et al. (2016) who referred the unit to the dinocyst Zone IV of Nøhr-Hansen (1993). The dinocyst assemblage of the Schönrockfjellet member suggest also a middle Albian age, confirming the previous age assignment of Århus (1991b). This age is inferred from the presence of Chichaouadinium vestitum, Pseudoceratium polymorphum, Litosphaeridium arundum, Pseudoceratium expolitum and Odontochitina singhii. Furthermore, the upper part of the Schönrockfjellet member belongs to Subzone IV (2) (Fig. 10), as suggested by the common presence of Chichaouadinium vestitum.

\section{Offshore seismic sequences}

Sequences 1-3 (S1-S3; Figs. 3 and 7) occur in the Hammerfest Basin, the Fingerdjupet Subbasin (of the Bjørnøya Basin), parts of the Nordkapp Basin, and on the Bjarmeland Platform (Marin et al., 2014; 2016a). Interpreted clinoforms generally show progradational trends towards the south (varies from SE to SW). In the Fingerdjupet Subbasin, a more SE-directed progradational trend dominates. Note that S1-S2 are not present in the southwestern part of the Nordkapp Basin, suggesting that they never reached that far south. In the Nordkapp Basin, which is known for its many salt diapirs, the constant thickness of S1 and S2 on both sides of most salt diapirs indicate that the salt was not moving at this time and did not form a barrier that prevented clinoform progradation (cf.

Nilsen et al., 1995; Rojo et al., 2015). A short characterization of S1-S3 follows, and seismic lines showing details of the clinoforms in these 

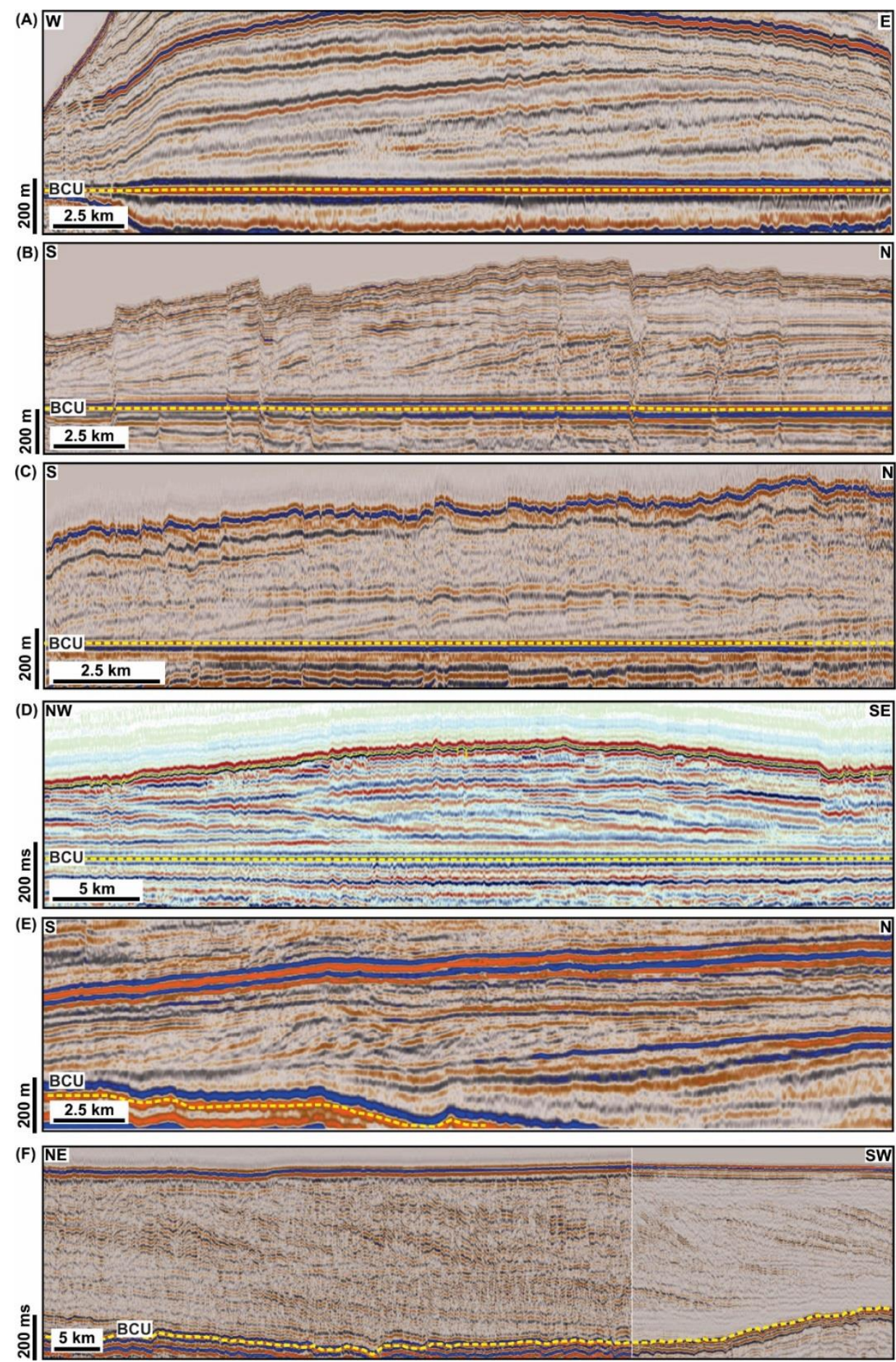

Fig. 11. Uninterpreted two-dimensional seismic profiles showing clinoform architectures in S1-S3 (based on Marin \& Escalona, 2014; Marin et al., 2016a). The profiles are flattened on the BCU. For location of the profiles see Fig. 1b, and for interpretation of the profiles see Fig. 12.

sequences are shown in Figures 11 and 12. For more details, see Marin and Escalona (2014) and

Marin et al. (2016a, 2016b). 


\subsection{Sequence 1 (S1)}

Sequence 1 display continuous parallel reflections of high to medium amplitudes. In the Hammerfest Basin, thickness variations in S1 are clearly controlled by normal faults as it is thicker in the graben areas and thinner against the basin margins (Figs. 8b). The top surface of S1 (Surface K1) has high amplitude and is interpreted to be a flooding surface (Figs. 7 and 12). In S1, clinoforms occur in the eastern part of the Nordkapp Basin, and southeastward prograding clinoforms occur in the Fingerdjupet Subbasin and in the western part of the Bjarmeland Platform (Figs. 11 and 12). In the Nordkapp Basin, they have sigmoidal geometries with average foreset angles of $1^{\circ}$ (Figs. 11 and 12), reliefs increasing basinward from $130 \mathrm{~m}$ to $400 \mathrm{~m}$, and progradational direction towards the SW. The clinoforms downlap either against the BCU or Surface K0. Low seismic resolution in combination with the limited thickness of the Knurr Formation on the Bjarmeland Platform and the Norsel High (e.g. 7224/7-1: $30 \mathrm{~m}, 7224 / 6-1: 16 \mathrm{~m}$, and 7226/11-1: $6 \mathrm{~m}$ ), occasionally makes it difficult to distinguish whether the clinoforms downlap onto the BCU or Surface K0. On the Bjarmeland Platform, the latter surface is represented by a condensed carbonate horizon inferred to be the top of the Klippfisk Formation, which here, is considered to be a lateral equivalent to S0 in the Hammerfest Basin (Fig. 3). The shelf-edge trajectory is ascending and topset developments are common, whereas bottomsets are poorly developed. The clinoforms in S1 are interpreted to be of a shelf-slope-basin type, recording a shelf-margin that successively built into deeper water. The sigmoidal clinoform geometries may point to mudstone-prone foresets with thin sandstones only occurring in the shelf topsets. The lack of bottomsets may indicate strong bottom currents parallel to base-of-slope (e.g. Cattaneo et al., 2007).

Clinoforms in the western part of the Bjarmeland Platform are oblique parallel with reliefs of 35-60 $\mathrm{m}$ and steep foreset angles with an average of 5-8 (Fig. 11 and 12). The clinoforms have high seismic amplitude and descending trajectories, indicating sand-prone foresets and high rates of accretion, respectively. It is suggested that they represent a sand-dominated deltaic shoreline that prograded rapidly to an outer shelf position (Figs. 11 and 12). Progradational wedges characterized by similarly steep and sand-prone clinoforms occasionally form in front of high-supply, storm-dominated 

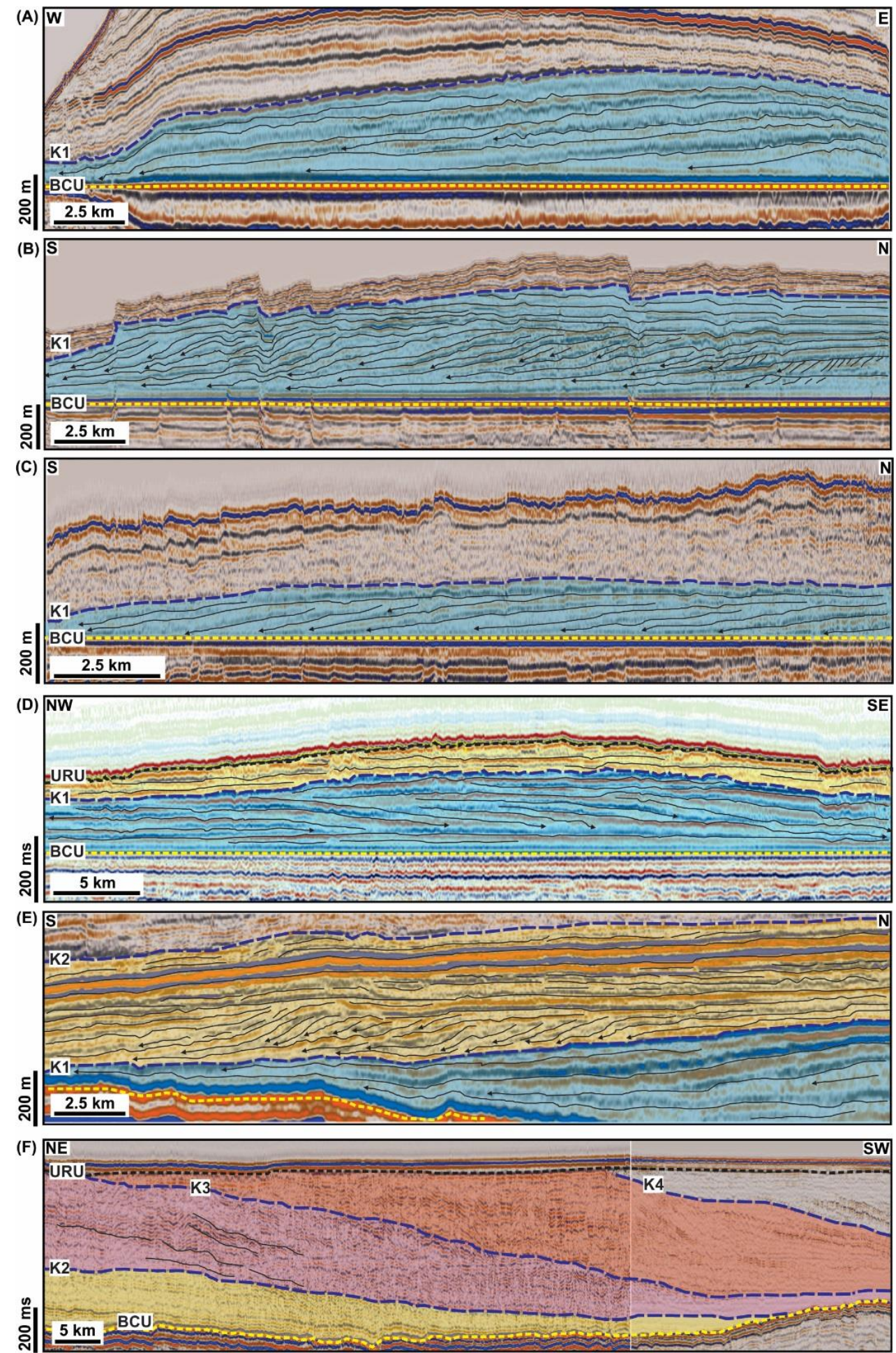

Fig. 12. Interpretation of the two-dimensional seismic profiles shown in Fig. 11. For location of the profiles see Fig. 1b. (A) Profile from the Nordkapp Basin through S1. Note the low angle (c. $1^{\circ}$ ) and the extensive lengths of the foresets (>30 km). (B) Profile from the western Bjarmeland Platform through S1 showing steep-angled, oblique parallel to sigmoidal clinoforms. (C) Profile from the north central Bjarmeland Platform through S1. (D) Profile from the Olga Basin showing S1 clinoforms that migrated in a SE-ward direction from the Svalbard Platform. (E) Profile from the Nordkapp Basin through S2. Note how the steep-angled S2 clinoforms downlap onto the K1 surface. (F) Composite profile from the area south of the Nordkapp Basin showing the successive southward migration of S2, S3 and S4. Because of poor seismic quality in this area, internal reflections are difficult to trace. Note the SW-ward thinning of the sequences. 
shorelines (Hernández-Molina et al., 2000). In the southwestern part of the Fingerdjupet Subbasin, the clinoforms are oblique to sigmoidal and their relief increase to $125-220 \mathrm{~m}$ whereas their foreset angles are reduced to $1.5-5^{\circ}$. They typically show flat to descending or low-angle ascending trajectories, and a general basinward increase in seismic amplitude. These clinoforms are therefore interpreted as a shelf-margin system that built basinward aided by a relative sea-level fall. The clinoform geometries suggests generally mudstone-prone foresets. However, steep foresets, descending trajectories, and the local occurrence of bottomsets, suggests that sediments periodically was bypassed down-slope from the shelf and onto the basin floor.

Along the strike to the NE, the foreset angles of the clinoforms gradually decrease, and in the western part of Bjarmeland Platform, sigmoidal clinoforms with reliefs of 85-110 m and foreset angles around $1^{\circ}$ dominate. It is suggested that they formed laterally away from to the main sediment source and may thus be dominated by mudstone.

\subsection{Age of $S 1$}

The distribution and the relative abundance of dinocysts within S1 was studied in four wells $7120 / 1-2,7120 / 2-2,7121 / 5-1$ and 7121/5-2. The presence of only sparse dinocyst assemblages in the wells 7120/1-2 and 7120/2-2 gave a very broad age range, (i.e. a latest Ryazanian/Valanginian or younger, see Marin et al., 2016a). The presence of Systematophora palmula and Lagenorhytis delicatula indicate reworking of Ryazanian strata whereas the record of Gonyaulacysta dualis and Paragonyaulacysta suggest reworking of Kimmeridgian to Ryazanian strata. Moderately good preservation and diversity of dinocyst in wells 7121/5-1 and 7121/5-2 narrow the age of S1

significantly. The most characteristic dinocysts within S1 are: Batioladinium longicornutum, Stanfordella fastigiata and Muderongia simplex subsp. microperforata sensu Nøhr-Hansen (1993). The presence of Oligosphaeridium abaculum in the lower part of the sequence suggests a Hauterivian age for this interval. The middle and upper part of the sequence is referred to the lower Barremian (Subzone I (2)), based on the occurrence of rare P. anaphrissum. Therefore, $\mathrm{S} 1$ is suggested to be of a latest Valanginian/earliest Hauterivian to early Barremian age (Fig. 10). 
Reflections in S2 vary from parallel continuous with medium amplitudes in the Hammerfest Basin to clinoforms that prograded to the SW in the Nordkapp Basin (Figs. 8, 11c and 12c). The top surface of the sequence (Surface K2) which show high to medium amplitudes, is interpreted as a flooding surface (Figs. 3, 7 and 12c). An erosional unconformity is present above the flooding surface and locally cuts down into it. The unconformity are penetrated in well 7231/04-U-01 and 7321/7-1 and have traditionally defined the boundary between the Kolje and Kolmule formations (Bugge et al., 2002; Figs. 3 and 7). The clinoforms typically downlap onto the top surface of the underlying sequence (Surface K1; Figs. 12c) or onto the condensed limestones of the Klippfisk Formation, Smelror et al., 1998; Bugge et al., 2002; Fig. 3).

In the Nordkapp Basin a wedge-shaped clinoform package with a flat to descending trajectory occur on top of the low-angle clinoforms of S1. These clinoforms have reliefs of 70-60 m, oblique parallel geometries and steep foreset angles with an average of $1.5-6^{\circ}$, all suggesting rapid progradation under relative sea-level fall (Figs. 11 and 12).

\subsection{Age of $S 2$}

Sequence 2 was studied in core and SWC samples from five wells 7019/1-1, 7120/1-2, 7120/2-2, 7121/5-1 and 7121/5-2. The upper of the two samples from well 7019/1-1 yielded reworked Early to Middle Jurassic dinocysts (Nannoceratopsis gracilis, Nannoceratopsis pellucida and Nannoceratopsis ridingii). The most important Early Cretaceous age diagnostic dinocysts observed within S2 are: Atopodinium haromense, Circulodinium brevispinosum, Dingodinium cerviculum, Nyktericysta vitrea, Odontochitina operculata, Palaeoperidinium cretaceum, Pseudoceratium nudum, Pseudoceratium cf. retusum, Vesperopsis longicornis and Vesperopsis mayi. The lower part of S2 is tentatively dated from latest Barremian to early late Aptian (i.e. dinocyst Subzone I (3) to dinocyst Subzone III (1) of Nøhr-Hansen, 1993; Fig. 10). The dinocyst assemblages from the 7120/2-2 well are less diverse, and the inferred age for the upper part of S2 is late early Aptian to middle late Aptian (Fig. 10). 
Reflectors in S3 varies from parallel continuous with medium amplitude to chaotic. Where it is not truncated by the URU, the top surface of S3 (Surface K3) is characterized by low amplitude in some areas (e.g. the Hammerfest Basin) and is consequently difficult to map. It is, however, interpreted as a flooding surface because younger sequences clearly downlap onto Surface K3. In the western part of the Bjarmeland Platform, clinoforms with oblique parallel to tangential geometries are observed to prograde to the SE (Figs. 11 and 12). In the Fingerdjupet Subbasin, clinoforms with reliefs of 40-65 $\mathrm{m}$, foreset angles up to $11^{\circ}$ and oblique tangential geometries occur locally in association with basin bounding faults. These clinoforms are bidirectional with dip directions from SE-NW and from NW-SE.

In the Fingerdjupet Subbasin, the small-scale, steep-angled clinoforms with opposing dipdirections, suggests the presence of a deltaic system with several protuberances that prograded towards the SE and filled a local depocentre. The scale and local fault-associated occurrence suggests that this system is not related to the large-scale palaeo-drainage system investigated here. Thus, it is speculated that these clinoforms formed in response to fault activity along the northern margin of the Fingerdjupet Subbasin (Marin et al., 2016b).

\subsection{Age of $S 3$}

Dinocysts from S3 were studied on three DC and one SWC samples from the 7121/5-1 well (interval between $1574.0 \mathrm{~m}$ to $1886.0 \mathrm{~m}$ ). The most characteristic dinocysts for S3 are: Odontochitina operculata, Palaeoperidinium cretaceum and Vesperopsis mayi. The topmost sample (1589.0 m; DC) yields furthermore Leptodinium cancellatum, Rhombodella paucispina and Chichaouadinium vestitum. If these species are considered in situ, then the upper part of S3 may be referred to the dinocyst Subzone III (1) of Nøhr-Hansen (1993) and dated to early middle Albian (Fig. 10). The lower and middle parts of S3 yields also Dingodinium cerviculum. The last occurrence of the species is considered a good marker for uppermost Aptian to lowermost Albian (e.g. Nøhr-Hansen, 1993; Fig. 10). The middle part of the S3 (1775.0 m; SWC) yields Surculosphaeridium longifurcatum. The first occurrence of the species was dated to $111.16 \mathrm{Ma}$ (Williams et al., 2004), suggesting that this part of the sequence is not older than early Albian. The base of S3 (1886.0 m; DC) yields also Circulodinium 
brevispinosum. The last occurrence of the species in NE Greenland is observed in the early Albian (Nøhr-Hansen, 1993). Based on these observations, a latest Aptian/earliest Albian to an early middle Albian age is suggested for S3 (Fig. 10).

\section{Discussion}

\subsection{Onshore-offshore age-correlations}

Based on the biostratigraphy established in this study, it is clear that the onshore system, agevise, corresponds to Sequences 1-3 in the offshore areas (Figs. 3 and 10). Detailed one to one correlations are not possibly at present due to data limitations. However, it is suggested that the Rurikfjellet Formation (Valanginian-Hauterivian/lower Barremian) correlate to S1 (uppermost Valanginian/Hauterivian-lower Barremian), the Helvetiafjellet Formation (lower Barremian-lower Aptian) and the Dalkjegla and Innkjegla members of the Carolinefjellet Formation (lower Aptian to upper Aptian) to S2 (uppermost Barremian-upper Aptian), and the remaining part of the Carolinefjellet Formation (Langstakken, Zillerberget and Schönrockfjellet members, upper Aptianmiddle Albian) to S3 (uppermost Aptian-lower/middle Albian).

The lower Aptian flooding surface that separates the Helvetiafjellet and Carolinefjellet formations onshore (Figs. 3-6) may thus not correlate to any of the sequence-bounding maximum flooding surfaces offshore (i.e. Surface K2; Figs. 3 and 6). Seismic resolution may have hampered its recognition offshore, but a minor flooding surface have been reported in the Fingerdjupet Subbasin (the stippled line that separates the Knurr and Kolje formations in well 7321/7-1 in Fig. 7). Although topset truncations occur locally within the offshore sequences, the lower Barremian subaerial unconformity at the base of the Helvetiafjellet Formation in Svalbard have not been detected in seismic or well data offshore. This may indicate that it is: 1) below seismic resolution, or 2) not present south of Svalbard but instead is time-equivalent to a marine correlative conformity surface offshore. Although a lower Barremian unconformity is recognized at the base of the Kolje Formation in large parts of the western Barents Shelf (Smelror et al., 1998; Bugge et al., 2002), its relation to the onshore unconformity is unclear. How much time the onshore unconformity represent is not known. However, based on the occurrence of Barremian dinocysts below and early Barremian dinocysts above 
the unconformity (Grøsfjeld, 1992; Fig. 10), it is suggested that the time of subaerial exposure must have been less than two million years. This estimate also seems likely when it is taken into consideration that the Barremian stage only lasted for about five million years (Fig. 10).

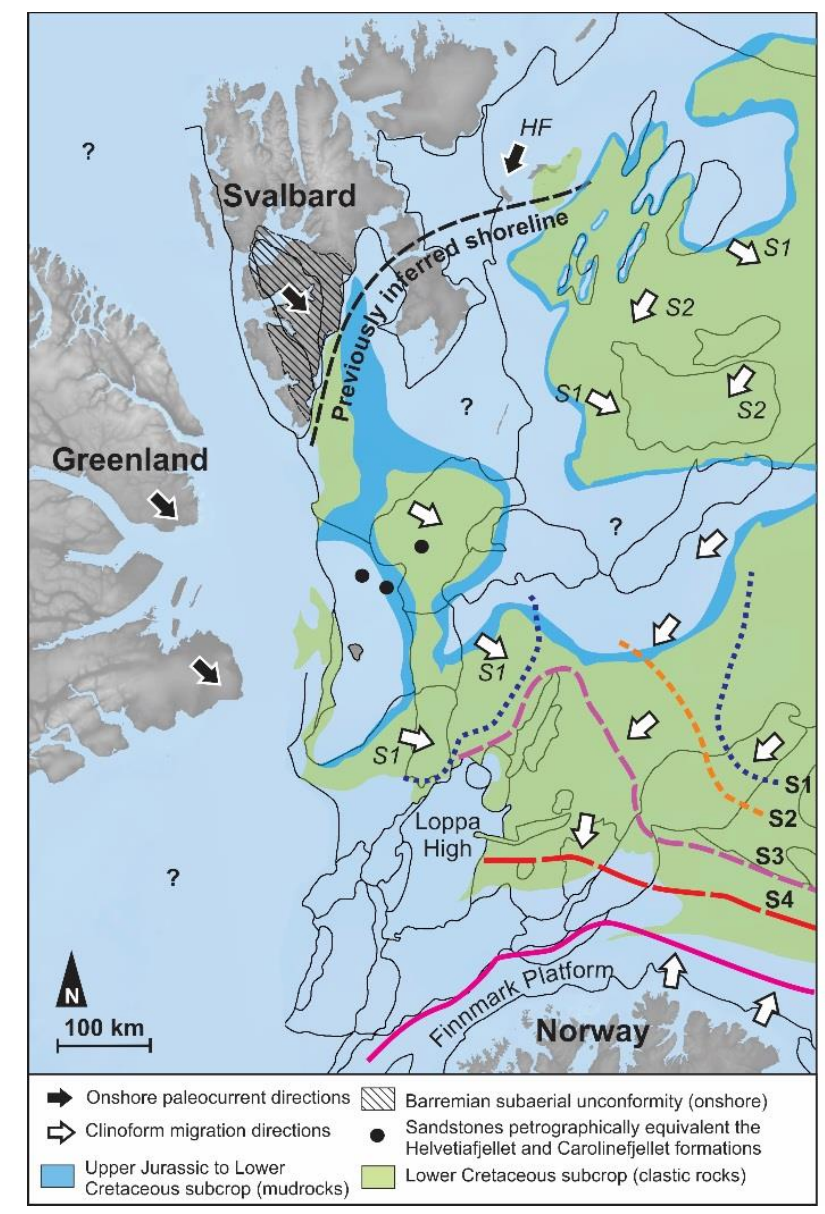

Fig. 13. Map showing minimum extent of the lower Barremian subaerial unconformity in Svalbard (hatched area) and the distribution of Upper Jurassic to Lower Cretaceous subcrops on the Barents Shelf. The map also summarizes onshore palaeocurrent directions (black arrows), offshore clinoform migration directions (white arrows), and the final shelf-break positions of S1-S3 (stippled lines annotated S1-S3). The final position of the S4 shelf-break is also shown just to illustrate the progradational nature of the Lower Cretaceous system. An adjacent shelf break is also inferred to have existed along the north sloping margin of the Finnmark Platform (pink line). The clinoform migration directions on the western Barents Shelf are based on Marin and Escalona (2014), Marin et al. (2016a), and Kairanov et al. (2015), whereas the directions on the eastern side is based on Kayukova et al. (2014). The onshore palaeo-current data from Svalbard are based on Steel et al. (1978), Nemec (1992), Gjelberg and Steel (1995, 2013), Midtkandal and Nystuen (2009) and the present study. Onshore data from Greenland are based on Dypvik et al. (2002). According to models by Gjelberg and Steel (1995) and Steel et al. (2000) a shoreline marking the regressive-transgressive turn-around point of the onshore depositional system developed just south of Svalbard in the Barremian (marked "previously inferred shoreline"). The map forms the framework for the regional palaeogeographic reconstructions shown in Fig. 14. 
In Svalbard, the amount of incision at the base of the Helvetiafjellet Formation ranges from some few to several tens of meters (Figs. 3 and 6), generally decreasing southward (Gjelberg and Steel, 1995, 2013). The latter reflects differential uplift and southward tilting of the Svalbard Platform and the adjacent land areas (e.g. the Lomonosov High, Fig. 2). The unconformity, however, is also present in southernmost Spitsbergen (Edwards, 1976; Grundvåg and Olaussen, 2017) implying that the entire outcrop area at one stage was subaerially exposed in the early Barremian (Figs. 3 and 13). The consequence of the exposure was a significant forced regression with bypass of a considerable volume of eroded sediments towards the southeast (Gjelberg \& Steel, 1995, 2013; Midtkandal \& Nystuen, 2009). The offshore areas south of Spitsbergen was concurrently little affected by the uplift, and in combination with deeper water and higher rates of subsidence, subaerial exposure of the deeper shelf areas south of Svalbard was prevented. These basinal areas instead offered accommodation space and acted as depocentres for sediments eroded from the uplifted shelf. This promoted rapid southward progradation of the deltaic system (Fig. 13). Due to the lack of data between Svalbard and the Fingerdjupet Subbasin, it is difficult to estimate the rate of progradation for this large-scale system. Based on the age assignment presented here (Fig. 10), it may be speculated that the upper part of the Rurikfjellet Formation and the Barremian unconformity in Svalbard, down-dip, correlates to the clinoforms of S1 in the Fingerdjupet Subbasin.

Grab samples containing sandstones of similar petrographic character to the ones in the Helvetiafjellet and the Carolinefjellet formations have been described from the shallow banks $200 \mathrm{~km}$ south of Spitsbergen (Edwards, 1975; Fig. 13). The sandstones were suggested to be locally derived, and their distribution fits well with the subcrop map shown in Fig. 13. Biostratigraphic studies of shale samples from the same data set (Bjærke \& Thusu, 1976) reveal a mixture of non-age diagnostic, Jurassic, Cretaceous, and Palaeogene palynomorph assemblages. According to Bjærke and Thusu (1976), Oligosphaeridium complex occurred in several of the investigated shale samples, partly resembling the Valanginian to Hauterivian dinocyst assemblage described in the Rurikfjellet Formation in the present study (Fig. 10). 
Three primary source areas are suggested to have provided sediments to S1-S3 (Valanginianlower middle Albian; Fig. 14). The most important one during the earliest stages of the shelf-margin accretion (S1) was located to the W and NW (Fig. 14a and 14b). This is indicated by the presence of the two S- and SE-ward thinning, shallow marine wedges in the upper part of the Rurikfjellet Formation (Figs. 3 and 14b). In addition, SE-ward directed clinoforms with steep foresets, descending trajectories, and high amplitude foresets occur in the Fingerdjupet Subbasin (Figs. 12 and 13). As a result of differential uplift, the NW source area became increasingly important during the earliest Barremian and deposition of S2 and the Helvetiafjellet Formation (Fig. 14c). This is indicated by the presence of SE-ward directed oblique clinoforms in the Fingerdjupet Subbasin. The progradation direction coincides with the SE-oriented palaeocurrents reported in the fluvial Festningen Member of the Helvetiafjellet Formation on Spitsbergen (Steel et al., 1978; Gjelberg and Steel, 1995; Midtkandal and Nystuen, 2009; Fig. 13). A less important source area was located NE of the Barents Shelf. In this region, including Kong Karls Land and the Olga Basin, NE-SW-striking folds controlled the sediment dispersal by funneling the fluvio-deltaic system in a SW-ward direction (Kairanov et al., 2015;

Olaussen et al., pers. comm., 2016). The folds were the result of pre-Barremian inversion of older Palaeozoic rift basins. In the Valanginian to Hauterivian, the northeastern source area had little influence on sedimentation in Spitsbergen and the western Barents Shelf area (Fig. 14a and 14b). Due to increased volcanic activity (e.g. extruded basaltic lava flows in Kong Karls Land) and thermal doming in the late Barremian and Aptian, it apparently became more important (Fig. 14c). In eastern Svalbard, this change is seen by an upwards change from quartzitic sandstones in the lower part of the Helvetiafjellet Formation to volcanic arenites in its upper parts and in the overlying Carolinefjellet Formation (Edwards, 1979; Maher, 2004). In addition, SW-ward directed clinoforms occur in S3. Uplifted terrain on the Loppa High and the Finnmark Platform locally fed fan deltas along on the basin margins, as well as submarine fans in the adjacent basins (e.g. the Hammerfest Basin; Seldal, 2005; Sattar et al., 2017; Fig. 14). However, these localized sediment source areas played a more important role during deposition of Sequence 0 (Fig. 14a; not discussed here). 
The lower Barremian subaerial unconformity at the base of the Helvetiafjellet Formation occur in all the investigated outcrops (Figs. 5, 6 and 13). Based on the present day areal extent of the unconformity in Spitsbergen (c. $14.000 \mathrm{~km}^{2}$; Fig. 13), it becomes clear that uplift of Svalbard itself could not have contributed with enough sediments to account for the thickness and the volume of the Lower Cretaceous succession reported in the western Barents Shelf. It may therefore be speculated that the northern margin of the Barents Shelf, the Lomonsov High, NE Greenland, and other Arctic terranes such as the Chukchi Borderland and the disintegrated Crockerland of Embry (1992) together formed a large source area to the north and northwest of Svalbard prior to the opening of the Canada Basin (Fig. 2; e.g. Miller et al., 2006). Other terranes in the E and NE such as uplifted parts of the Kara Shelf, remnants of the Late Palaeozoic-Triassic Taimyr Foldbelt and the Siberian Traps (Zhang et al., 2013), and the more distant South Anyui Orogen (Nikishin et al., 2014), probably became increasingly important source areas during deposition of the younger sequences (S4-S6).

In the Nordkapp Basin, the depocentre was systematically displaced towards the SW (Fig. 14; Bugge et al., 2002), and the final shelf-break for the investigated system (S1-S3) developed just south of the Nordkapp Basin (Figs. 13 and 14). The regional-scale drowning of the shelf in late Aptian to earliest Albian times may relate to a combination of several factors including circum-Arctic platetectonic reconfiguration, regional sag-like subsidence related to thermal cooling of the lithosphere, abrupt shut-down of sediment supply leading to relative sea-level rise due to delta top subsidence and compaction, eustatic sea-level rise, auto-retreat mechanisms, or a combination of all these factors. However, the regional extent of the flooding as well as the switch to a more eastern to northeastern source terrain in the younger and succeeding sequences (S4-S6; Marin and Escalona, 2014) suggests that large-scale tectonics had a major influence on the sequence development and clinoform accretion. Allogenic forcing is also supported by the dramatic height increase of the clinoforms from less than $130 \mathrm{~m}$ in $\mathrm{S} 1$ to more than $500 \mathrm{~m}$ in S4 (not considered here, see Marin et al., 2016a). This may indicate either an increase in basin subsidence due to fault activity or salt tectonics, or that the clinoforms prograded into a deeper area of the Nordkapp Basin.

\subsection{Sediment partitioning and sand distribution}


The low-amplitude reflections observed in the foresets of the majority of the larger-scale clinoforms (relief $>150 \mathrm{~m}$ ) in S1-S3 may indicate that they are generally mudstone-dominated. This notion is also confirmed by the gamma ray logs from the many exploration wells that have penetrated the Lower Cretaceous succession in the SW Barents Sea. The apparent lack of sandstone in the SW therefore suggests that most of the sand was trapped in the northern and northwestern areas of the shelf. Sand-grade sediments were mostly stored in the clinoform topsets in coastal plain, regressive shoreline, and inner shelf environments, particularly 

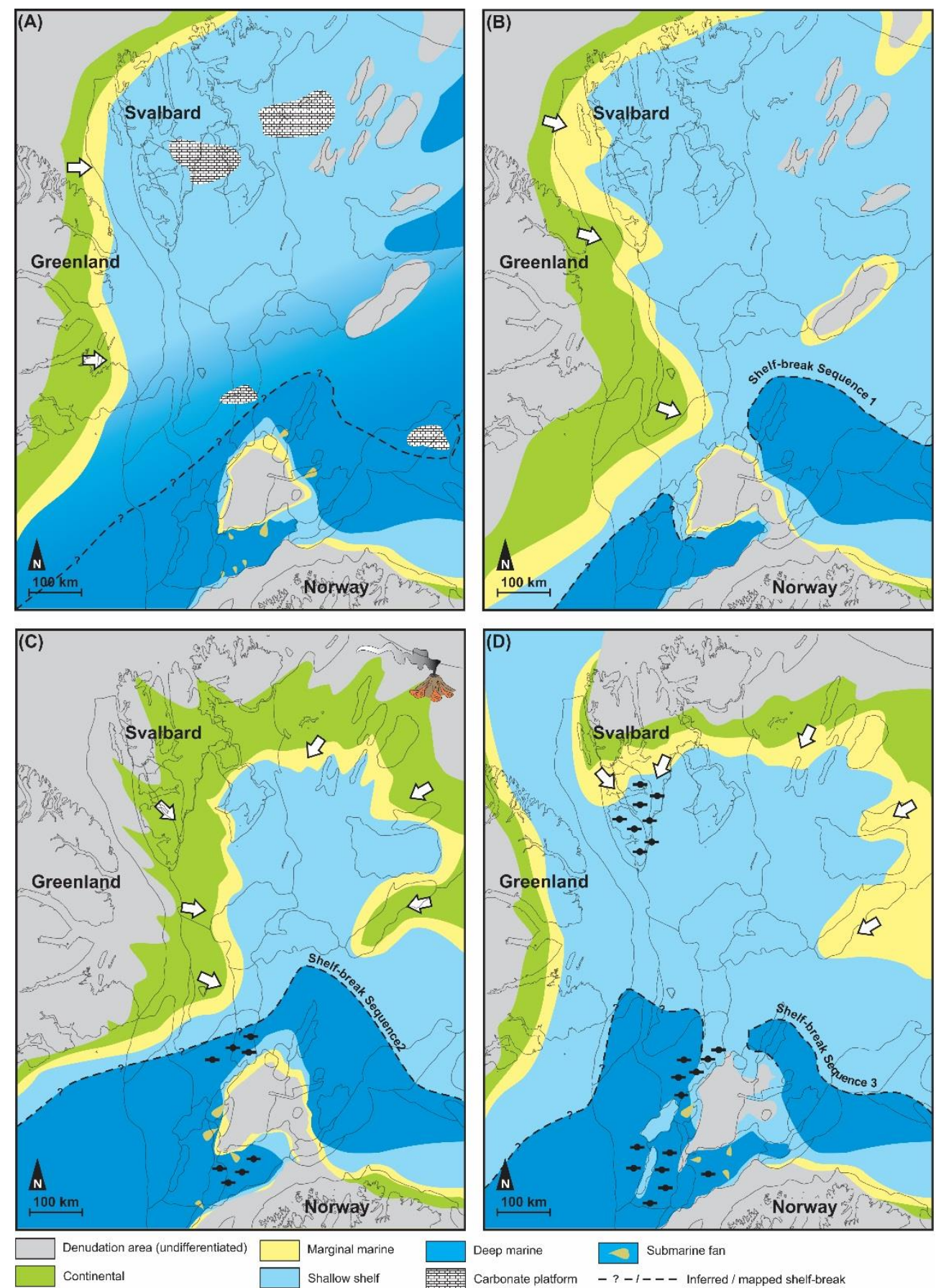

Fig. 14. Palaeogeographic reconstructions of the western Barents Shelf showing: (A) the earliest Valanginian at c. $139 \mathrm{Ma}$ (Myklegardfjellet Bed and S0) characterized by sediment starvation and the formation of carbonate platforms, (B) the latest Hauterivian at c. $132 \mathrm{Ma}$ (upper part of Rurikfjellet Formation and S1) with shallow marine wedges locally building out from a source area to the west (i.e. Greenland), (C) the middle to late Barremian at c. $129 \mathrm{Ma}$ (the Helvetiafjellet Formation and S2) with a fluvio-deltaic system that was forced southeastward following uplift and southward tilting of the shelf (which created the subaerial unconformity in Svalbard), and (D) the latest Aptian at c. $114 \mathrm{Ma}$ (the Carolinefjellet Formation and S2 to S3) when large parts of the platform was flooded. A seaway may have connected the Barents Shelf with the Canada Basin in the latest Aptian to earliest Albian, enabling cold, polar water to invade the shallow shelf. 
during periods of relative rise of sea-level. Onshore, this is clearly demonstrated by the large amount of sandstone in the upper part of the overall transgressive Helvetiafjellet Formation (the Glitrefjellet Member, Figs. 3-6). The sediment partitioning may also reflect proximal to distal trends, which are typical for graded shelf systems (Swift and Thorne, 1991), or physiographic and hydrodynamic conditions in the basin (Helland-Hansen and Hampson, 2009). Although the successive migration of deltas and shorelines across the shelf is the main mechanism of transporting sediments to the shelfedge, storms play a major role in offshore sediment transport on many shelves by eroding sediments that aggrade above the shelf equilibrium profile (Seilacher, 1982; Prattson et al., 2004). Storm-eroded sediments, particularly mud, may be driven across a low-gradient sloping shelf under the combined influence of gravity and storm waves (Traykovski et al., 2000; Wright et al., 2001; MacQuaker et al., 2010).. In addition, storms indirectly may aid highly concentrated suspended fluid muds to escape the energy fence of the inner shelf through, storm-modified hyperpycnal flows (Myrow et al., 2002; Pattison, 2005) and offshore flushing of estuaries and prodelta environments during river floods (Neil and Allison, 2005 The combined result of these processes is a net basinward transport of mud across the shelf and onto the upper slope where instability and gravity-driven processes dominate. Thus, in some modern deltas, a mud-prone shoreline-detached subaqueous platform tend to form in front of the subaerial delta (Alexander et al., 1991; Swenson et al., 2005; Patruno et al., 2015). The rollover-point of such subaqueous deltas are in some modern cases separated from its shoreline by more than $100 \mathrm{~km}$ (Swenson et al., 2005; Patruno et al., 2015). It has also been reported that some modern subaqueous deltas may show higher accretion rates than its associated shoreline, which in some extreme cases experience net erosion (e.g. Nittrouer et al., 1996). Accretion rates of $12-17 \mathrm{~m}$ per year have been reported from the subaqueous delta of the Ganges-Brahmaputra (Michels et al., 1998). Good examples of modern subaqueous deltas include those of the western Adriatic Shelf (Cattaneo et al., 2003; 2007), the Gulf of Papua (Walsh et al., 2004), the South Yellow Sea (Yang and Liu, 2007), and the Bay of Bengal (Kuehl et al., 2005).

It may be speculated that sigmoidal-shaped, low-angle clinoforms in S1 in the Nordkapp Basin and on the Bjarmeland Platform, represent subaqueous delta-type clinforms similar to those described 
above. However, to our current knowledge, subaqueus deltas are more typical of relative sea-level stillstands and most Holocene examples occur in inner shelf settings at relatively shallow waters (Patruno et al., 2015). The clinoforms investigated here (see also Marin et al., 2016a), both in size and geometries (Fig. 12), more resemble prograding shelf-prism-scale clinoforms (Patruno et al., 2015). Shelf-prism-type clinoforms commonly have paralic to shallow marine topsets, and good reservoir sands may thus be expected in these segments . Although turbidite lobes and mass transport complexes occur in places, the sandstone content in the clinoform slope and toe-sets are expected to be generally low. However, given the right conditions (i.e. mode and rate of sediment supply, shelf width, relative sea-level etc.; Steel et al., 2000), good reservoir sands may also occur in the slope to basin floor region of some clinoforms. The inner shelf in the present case was most likely a zone of limited accommodation space; the eroded volume of sediments that was shed of from the uplifted Svalbard platform could not be stored on the shallow inner shelf. The large amount of bypassed sediments in combination with available lateral accommodation space ultimately gave rise to prograding clinoform successions further offshore. .

In Svalbard, tempestite deposits dominated by hummocky cross-stratification occur in both the Rurikfjellet and Carolinefjellet formations and indicate that the shelf sea frequently experienced storm activity. Apparently, strong longshore currents and tidal currents also influenced the sediment distribution on the shelf (Birkenmajer, 1966; Maher et al., 2004). Tidal deposits in estuarine and coastal plain settings occur in the overall transgressive Helvetiafjellet Formation at several locations in central Spitsbergen (Gjelberg and Steel, 1995; Midtkandal and Nystuen, 2009), including in some of the inferred most proximal outcrop sections (e.g. at the Festningen section, Fig. 1). Due to the low angle of the coastal plain, tidal currents could penetrate several tens to hundreds of kilometers upstream, similar to that reported from some modern rivers that drain low-angle coastal plains (e.g. the Mississippi River; Holle, 1951; the Orinoco River and its predecessor, Escalona and Mann, 2006). This suggests that tidal currents in combination with frequent storm activity, and strong longshore currents periodically played a major role in the sediment distribution in the Svalbard area by trapping 
sand-grade sediments within estuaries, deltas, and distributary channels, particularly during the longterm rise in relative sea-level that followed the forced regression in the early Barremian.

Smaller-scale (relief $<70 \mathrm{~m}$ ) clinoforms with steep-angled foresets (up to eight degrees dip), typically characterized by high amplitude reflections, occur in the proximity of faults or along the margin of some palaeo-highs (e.g. S3 in the northern part of the Fingerdjupet Subbasin). These clinoforms represent more localized, and potentially sand-rich deltaic/shallow marine systems that were not genetically or directly related to the large-scale palaeo-drainage system discussed here. The different systems did however interact in the areas were they met (Marin et al., 2014). The sandstonedominated shallow marine parasequences in the Kikutodden Member of the Rurikfjellet Formation in southernmost Spitsbergen (Edwards, 1976; Mørk, 1978; Figs. 4 and 5e) may represent an onshore facies analog to these inferred sand-rich clinoforms in the Fingerdjupet Subbasin (Grundvåg and Olaussen,2017.). Based on the onshore dip-extent of the onshore parasequences (from Kikutodden to Fotografryggen, minimum $70 \mathrm{~km}$, see Fig. 1) and their limited lateral facies variation across southern Spitsbergen (c.f. Edwards, 1976, Mørk, 1978), it is suggested that they probably extended several tens of kilometers southward (offshore) before they terminated (Grundvåg and Olaussen, 2017).

\subsection{Lower Cretaceous clinoforms onshore?}

Although Steel et al. (2000) interpreted the presence of a canyon head in a shelf-edge setting at Kvalvågen in eastern Spitsbergen (later disputed by Onderdonk \& Midtkandal, 2010), shelf-marginscale clinoforms or facies indicative of such features have not been reported from the Lower Cretaceous in Svalbard. However, the low-angle nature and the large size of the clinoforms in combination with outcrop limitations may have hindered their recognition. Some of the mudstoneprone, low-angle clinforms in the offshore areas have dip-angles of less than one degree, and slope lengths of more than 30-40 kilometers (Fig. 8). If clinoforms occur onshore, their slope segment could easily be hidden in the shale-dominated and commonly scree-covered Rurikfjellet Formation which has an average thickness of $200 \mathrm{~m}$ but reaches a thickness of $400 \mathrm{~m}$ in places (Figs. 3, 4 and 5). In general, the topset of these inferred low-angle clinoforms could have been eroded during formation of 
the lower Barremian subaerial unconformity at the base of the Helvetiafjellet Formation, creating a subtle toplap situation, which is difficult, not say impossible to recognize in an outcrop.

A c. $150 \mathrm{~m}$ thick succession of gravity flow deposits which include rafted blocks of coastal plain origin has been reported from the onshore wells Dh-1 and Dh-2 (Braathen et al., 2012; Figs. 5a and 6). Recent dinocyst studies indicate an early late Hauterivian age for these sediments (Śliwińska et al., 2016; Fig. 6). Although gravity flow deposits occur in large slump scars in slightly younger strata, as reported from eastern Spitsbergen by Nemec et al. (1988) and Steel et al. (2000), similar deposits have not been encountered in any of the other investigated outcrop sections in Svalbard. The gravity flow deposits is overlain by a clearly regressive prodelta to delta front package (Fig. 5a), and the thickness of the deposits also indicates that there must have been enough relief in the area to accommodate such a succession and to allow for the initiation of turbidity currents and debris flows. An explanation for the thickness of the gravity flow deposits and their localized occurrence is that they represent lower slope to basin floor fans and mass transport complexes (MTCs) that accumulated in front of prograding and periodically unstable shelf-prism-scale clinforms. High-amplitude anomalies, probably also representing MTCs, are seen in the lower slope segment of several of the offshore sequences (e.g. Figs. 11 and 12). The late Hauterivian age of the MTC onshore, potentially highlight the inferred offlapping nature of the Lower Cretaceous system as it predates the lower Barremian unconformity and the Helvetiafjellet Formation, and thus record a hitherto unknown regression and shelf-edge development in Svalbard.

\section{Conclusions}

By combining new biostratigraphic data with conventional outcrop data from Svalbard and a sequence stratigraphic framework defined from well and seismic data offshore, this study shed new light on the palaegeographic development of the Lower Cretaceous in the northwestern part of the Barents Shelf. It is suggested that three offshore sequences (S1-S3) of latest Valanginian-earliest middle Albian age correspond and correlate to the Lower Cretaceous succession onshore Svalbard, which includes the Rurikfjellet (Valanginian-Hauterivian/early Barremian), Helvetiafjellet (early Barremian-early Aptian) and Carolinefjellet formations (early Aptian in its lower part, middle Albian 
in its upper part). Clinoforms within the offshore sequences generally show a south to southeastward progradation-direction, a trend which coincides with palaeocurrent directions in both the Rurikfjellet and Helvetiafjellet formations onshore. This strongly indicates that the onshore and the offshore depositional systems were parts of the same large-scale palaeo-drainage system. The presence of a regionally extensive subaerial unconformity onshore Spitsbergen indicates that the entire northwestern part of the shelf were uplifted and acted as a bypass zone during the early Barremian. The presence of Barremian dinocyts in the strata above and immediately below the unconformity further suggests a minor hiatus and that the shelf was exposed for only a relatively short period of time $(<2$ million years). Sediments eroded from the exposed shelf were forced southeastward and deposited in basinal areas where the amount of accommodation space were higher. High rates of sediment supply in combination with the low-gradient ramp setting and the lack of vertical accommodation space on the shallow inner shelf promoted basinward clinoform accretion. The apparent lack of sand in the slope and basin floor segment of the majority of the shelf-prism-scale clinoforms (relief $>150 \mathrm{~m}$ ) may relate to the physiographic conditions in the receiving basin (storm waves, along-shore currents plus strong tidal currents) resulting in a net basinward transport of mud. Apparently, sand was mostly trapped in paralic to inner shelf environments in the clinoform topsets. . Smaller scale (relief $<60 \mathrm{~m}$ ) clinoforms with steep foresets (up to $8^{\circ}$ dip) characterized by high amplitude reflections represent localized, and potentially sand-rich systems that interacted with the larger-scale clinoform systems. Due to outcrop limitations, clinoform geometries at the scale of shelf-prism are yet to be recognized onshore. However, based on the large scale (minimum slope lengths of 30-40 km) and low-angle geometries (foreset dips $<1^{0}$ ) of some of the offshore clinoforms, , it is speculated that clinoforms may be present in the up to 400 m thick Rurikfjellet Formation (Valanginan-Hauterivian/early Barremian). This may be evident by the occurrence of a $150 \mathrm{~m}$ thick succession of gravity flow deposits (including rafted blocks of coastal plain origin) overlain by a regressive prodelta slope to delta front package in the Rurikfjellet Formation in some of the onshore wells. The thickness of these deposits indicate that there must have been enough relief in the basin to accommodate such a succession and to allow for the initiation of turbidity currents and debris flows. We thus interpret the gravity flow deposits to represent lower slope to basin floor fans and mass transport complexes that accreted in front of a 
prograding shelf-slope system. The documented late Hauterivian age of the gravity flow deposits potentially highlights the inferred offlapping nature of the Lower Cretaceous system as they predate the lower Barremian unconformity, and thus record a hitherto unknown regression in Svalbard.

\section{Acknowledgments}

The authors are grateful to all the sponsors of the LoCrA consortium whom provided us financial support to carry out field work, as well as several $\mathrm{PhD}$ grants. We are also grateful to Lundin Norway for their generous support of a postdoctoral research grant to the first author. HN-H and KKS acknowledge Dorthe Samuelsen, Anette Ryge and Charlotte Olsen for preparing palynological slides. Additionally, KKS thanks NPD for lending slides from wells 7121/5-1 and 7121/5-2. SAG also received funding from the ARCEx project (Research Centre for Arctic Petroleum Exploration) which is funded by the Research Council of Norway (grant number 228107).

\section{References}

Alexander, C. R., DeMaster, D. J., Nittrouer, C. A., 1991. Sediment accumulation in a modern epicontinental-shelf setting. Mar. Geol. 98, 51-72.

Antonsen, P., Elverhøi, A., Dypvik, H. \& Solheim, A. 1991: Shallow bedrock geology of the Olga Basin area, nortwestern Barents Sea. AAPG Bull. 75, 1178-1194.

Basov, V.A., Vasilenko, L.V., Viskunova, K.G., Korago, E.A., Ko-rchinskaya, M.V., Kupriyanova, N.V., Povysheva, L.G., Preo-brazhenskaya, E.N., Pchelina, T.M., Stolbov, N.M., Suvorova, E.B., Suprunenko, O.I., Suslova, V.V., Ustinov, N.V., Ustritsky, V.I., Fefilova, L.A, 2009. Evolution of sedimentary environments of the Barents-North Kara palaeobasins in the Phanerozoic. Neftegaz. Geol. Teor. Prakt. 4, pp. 1-44.

Birkenmajer, K., 1966. Lower cretaceous tidal deposits of central vest Spitsbergen. Norsk Polarinstitutt Årbok 1964, 73-85.

Bjærke, T., Thusu, B., 1976. Cretaceous palynomorphs from Spitsbergenbanken, NW Barents Shelf. Norsk Polarinstitutt Årbok 1974, 258-262

Braathen, A., Bælum, K., Christensen, H.H., Dahl, T., Eiken, O., Elvebakk, H., Hansen, F., Hanssen, T.H., Jochmann, M., Lie, T., Johansen, T.A., Johnsen, H., Larsen, L., Mertes, J. Mørk, A., Mørk, M.B., Nemec, W.J., Olaussen, S., Oye, V, Røed, K., Titlestad, G.O., Tveranger, J., Vagle, K., 2012. The Longyearbyen $\mathrm{CO}_{2} \mathrm{Lab}$ of Svalbard, Norway - initial assessment of the geological conditions for $\mathrm{CO}_{2}$ sequestration. Nor. J. Geol. 92, 353-376.

Bugge, T., Elvebakk, G., Fanavoll, S., Mangerud, G., Smelror, M., Weiss, H.M., Gjelberg, J., Kristensen, S. E., Nilsen, K., 2002. Shallow stratigraphic drilling applied in hydrocarbon exploration of the Nordkapp Basin, Barents Sea. Mar. Petrol. Geol. 19, 13-37. 
Cattaneo, A., Correggiari, A., Langone, L., Trincardi, F., 2003. The late-Holocene Gargano subaqueous delta, Adriatic shelf. Mar. Geol. 193, 61-91.

Cattaneo, A., Trincardi, F., Asioli, A., Correggiari, A., 2007. The Western Adriatic shelf clinoform: energy-limited bottomset. Continental Shelf Res. 27, 506-525.

Corfu, F., Polteau S., Planke S., Faleide J.I., Svensen H., Zayoncheck, A., Stolbov, N., 2013. U-Pb geochronology of Cretaceous magmatism on Svalbard and Franz Josef Land, Barents Sea Large Igneous Province. Geol. Magazine 150, 1127-1135.

Dalland, A., 1981. Mesozoic sedimentary succession at Andøya, Northern Norway, and relation to structural development of the North Atlantic region. In: Gelogy of the North Atlantic Borderlands. Canadien Soc. Petrol. Geol. Mem. 7, 563-584.

Dalland, A., Worsley, D., Ofstad, K., 1988. A Lithostratigraphic Scheme for the Mesozoic and Cenozoic Succession Offshore Norway North of 62 N. NPD Bull. 4, 67 pp.

Doré, A.G., Lundin, E.R., Jensen, L.N., Birkeland, Ø., Eliassen, P.E., Fichler, C., 1999. Principal tectonic events in the evolution of the northwest European Atlantic margin. In: Fleet, A.J., Boldy, S.A.R. (Eds.), Petroleum Geology of Northwest Europe: Proceedings of the 5th Conference. Geol. Soc., London, pp. 41-61.

Dypvik, H., Nagy, J., Krinsley, D.E., 1992. Origin of the Myklegardfjellet Bed, a basal Cretaceous marker on Spitsbergen. Polar Res. 11, 21-31.

Dypvik, H., Håkansson, E., Heinberg, C., 2002. Jurassic and Cretaceous palaeogeography and stratigraphic comparisons in the North Greenland-Svalbard region. Polar Res. 21, 91-108

Dypvik, H., Nagy J., Eikeland T.A., Backer-OweK., Johansen H., 1991. Depositional conditions of the Bathonian to Hauterivian Janusfjellet Subgroup, Spitsbergen. Sed. Geol. 72, 55-78.

Edwards, M.B., 1975. Gravel fraction on the Spitsbergen Bank, NW Barents Shelf. Nor. Geol. Sur. Bull. 29, 205-217.

Edwards, M.B., 1976. Depositional environments in Lower Cretaceous regressive sediments, Kikutodden, Sørkapp Land, Svalbard. Norsk Polarinstitutt Årbok 1974, 35-50.

Edwards, M.E., 1979. Sandstone in Lower Cretaceous Helvetiafjellet Formation, Svalbard: bearing on reservoir potential of Barents Shelf. AAPG Bull. 63, 2193-2203.

Embry, A. F., 1992. Crockerland - the northwest source for the Sverdrup Basin, Canadian Arctic Islands. In: Vorren, T.O., Bergsager, E., Dahl-Stamnes, Æ.A., Holter, E., Johansen, B., Lie, E., Lund, T.B. (Eds.), Arctic Geology and Petroleum Potential. NPF Spec. Publ. 2, 205-216.

Escalona, A., Mann, P., 2006. Sequence-stratigraphic analysis of Eocene clastic foreland basin deposits in central Lake Maracaibo using high-resolution well correlation and 3-D seismic data. AAPG Bull. 90, 581-623.

Faleide, J. I., Vågnes, E., Gudlaugsson, S. T., 1993. Late Mesozoic-Cenozoic evolution of the southwestern Barents Sea in a regional rift-shear tectonic setting. Mar. Petrol. Geol. 10, 186-214. 
Faleide, J. I., Tsikalas, F., Breivik, A.J., Mjelde, R., Ritzmann, O., Engen, O., Wilson, J., Eldholm, O., 2008. Structure and evolution of the continental margin off Norway and the Barents Sea. Episodes 31, p. 82.

Gabrielsen, R.H., Grunnaleite, I., Rasmussen, E., 1997. Cretaceous and Tertiary inversion in the Bjørnøyrenna Fault Complex, south-western Barents Sea. Mar. Petrol. Geol. 14, 165-178.

Gjelberg, J., Steel, R.J., 1995. Helvetiafjellet Formation (Barremian-Aptian), Spitsbergen: characteristics of a transgressive succession. In: Steel, R.J., Felt, V.L., Johannesen, E.P., Mathieu, C. (Eds.), Sequence Stratigraphy on the Northwest European Margin. Elsevier, Amsterdam, pp. 571-593.

Gjelberg, J., Steel, R., 2013. Depositional model for the Lower Cretaceous Helvetiafjellet Formation on Svalbard - diachronous vs. layer-cake models. Nor. J. Geol. 92, 41-54.

Golonka, J., Bocharova, N.Y., Ford, D., Edrich, M.E., Bednarczyk, J., Wildharber, J., 2003.

Paleogeographic reconstructions and basins development of the Arctic. In: Golonka, J. (Ed.), Thematic Set on Paleogeographic Reconstruction and Hydrocarbon Basins: Atlantic, Caribbean, South America, Middle East, Russian Far East, Arctic. Mar. Petrol. Geol. 20, 211-248.

Grantz, A., Hart, P.E., Childers, V.A., 2011. Geology and tectonic development of the Amerasia and Canada Basins, Arctic Ocean. In: Spencer, A.M., Gautier, D., Stoupakova, A., Embry, A., Sørensen, K. (Eds.), Arctic Petroleum Geology. Geol. Soc., London Mem. 35, 771-799.

Grogan, P., Østvedt-Ghazi, A.-M., Larssen, G. B., Fotland. B., Nyberg, K., Dahlgren, S., Eidvin, T. 1999. Structural elements and petroleum geology of the Norwegian sector of the northern Barents Sea. In: Fleet, A.J., Boldy, A.R. (Eds.), Petroleum Geology of Northwest Europe. Proceedings $5^{\text {th }}$ Conference, 247-259.

Grogan, P., Nyberg, K., Fotland, B., Myklebust, R., Dahlgren, S., Riis, F., 2000. Cretaceous magmatism south and east of Svalbard: evidence from seismic reflection and magnetic data. Polarforschung 68, 25-34.

Grundvåg, S.-A., Olaussen. S., 2017. Sedimentology of the Lower Cretaceous at Kikutodden and Keilhaufjellet, southern Spitsbergen: implications for the onshore-offshore link. Polar Res. 36, 1302124, DOI: 10.1080/17518369.2017.1302124.

Grøsfjeld K., 1992. Palynological age constraints on the base of the Helvetiafjellet Formation (Barremian) on Spitsbergen. Polar Res. 11, 11-19.

Helland-Hansen, W., Hampson, G.J., 2009. Trajectory analysis: Concepts and applications. Basin Res. $21,454-483$.

Henriksen, E., Ryseth, A. E., Larssen, G. B., Heide, T., Rønning K., Sollid, K., Stoupakova, A. V. 2011. Tectonostratigraphy of the greater Barents Sea: implications for petroleum systems. In: Spencer, A. M., Embry, A. F., Gautier, D. L., Stoupakova, A. V., Sørensen, K. (Eds.), Arctic Petroleum Geology. Geol. Soc., London, Mem. 35, 163-195.

Hernández-Molina F.J., Fernández-Salas L.M., Lobo F., Somoza L., Díaz-del-Rio V., Alveirinho Dias J.M., 2000. The infralittoral prograding wedge: a new large-scale progradational sedimentary body in shallow marine environments. Geo-Mar. Letters 20, 109-117. 
Holle, C.G., 1951. Sedimentation at the mouth of the Mississippi River. In: Johnson, J.W. (Ed.), Coastal Engineering. Coastal Engineering Proc. 2, 111-129.

Houseknecht, D. W., Bird, K.J., Schenk, C.J., 2009. Seismic analysis of clinoform depositional sequences and shelf-margin trajectories in Lower Cretaceous (Albian) strata, Alaska North Slope. Basin Res. 21, 644-654.

Hurum, J.H., Roberts, A.J., Dyke, G.J., Grundvåg, S.-A., Nakrem, H.A., Midtkandal, I., Śliwińska, K.K., Olaussen, S., 2016. Bird or maniraptoran dinosaur? A femur from the Albian strata of Spitsbergen. Palaeontologia Polonica 67, 137-147.

Indrevær, K., Gabrielsen, R. \& Faleide, J.I., 2016. Early Cretaceous syn-rift uplift and tectonic inversion in the Loppa high area, southwestern Barents Sea, Norwegian Shelf. Journal of the Geological Society of London, Doi: 10.1144/jgs2016-066.

Kairanov, B., Marin, D., Escalona, A., Kayukova, A., 2015. Structural control in the progradation direction of the Lower Cretaceous clinoforms in the greater Barents Sea. Poster presented at: 3P Arctic Conference \& Exhibition: The Polar Petroleum Potential, Stavanger, Norway, September 29th October 2nd, 2015.

Kayukova, A.V., Suslova, A.A., Stoupakova, A.V., Kurasov, I.A. \& Gilaev, R.M. 2014. Cyclicity and petroleum prospects of Cretaceous in the Barents Kara Sea Region. In: Eriksen, S., Haflidason, H., Olesen, O., Husås, A.M. (Eds.), The Arctic Days Conference: Arctic Energy. Nor. Geo. Soc Abstracts and Proceedings 2, 53-54.

Koevoets, M., Abay, T. B., Hammer, Ø., Olaussen, S., 2016. High-resolution organic carbon-isotope stratigraphy of the Middle Jurassic-Lower Cretaceous Agardhfjellet Formation of central Spitsbergen, Svalbard. Palaeogeography, Palaeoclimatology, Palaeoecology 449, 266-274.

Kuehl, S.A., Allison, M.A., Goodbred, S.L., Kudrass, H., 2005. The Ganges-Brahmaputra Delta. In: Giosan, L., Bhattacharya, J.P (Eds.), River deltas: concepts, models and examples. SEPM Spec. Publ. $83,413-434$.

Langrock, U., Stein, R., Lipinski, M., Brumsack, H.J., 2003. Paleoenvironment and sea-level change in the early Cretaceous Barents Sea-implications from near-shore marine sapropels. Geo-Mar. Letters 23, 34-42.

Lawver, L. A., Muller, R. D., 1994. Iceland hotspot track. Geology 22, 311-314.

Lawver, L., Grantz, A., Gahagan, L., 2002. Plate kinematic evolution of the present Arctic region since the Ordivician. In: Miller, E.L., Grantz, A, Klemperer, S.L. (Eds.), Tectonic evolution of the Bering Shelf - Chukchi Sea - Arctic Margin and adjacent landmasses. GSA Bull. Spec. Papers 360, 337-362.

Lundin E.R., Doré, A.R., 1997. A tectonic model for the Norwegian passive margin with implications for the NE Atlantic: Early Cretaceous to break-up. J. Geol. Soc. 154, 545-550.

MacQuaker, J.H.S., Bentley, S.J., Bohacs, K.M., 2010. Wave-enhanced sediment gravity flows and mud dispersal across continental shelves: reappraising sediment transport processes operating in ancient mudstone successions. Geology 38, 947-950. 
Maher, H.D., 2001. Manifestations of the Cretaceous high arctic large igneous province in Svalbard. J. Geol. 109, 91-104.

Maher H.D., Hays T., Shuster R., Mutrux J., 2004. Petrography of the Lower Cretaceous sandstones of Spitsbergen. Polar Res. 23, 147-165.

Marin. D, Escalona, A., 2014. Architecture and distribution analysis of the Lower Cretaceous clinoforms in the Western Barents Sea. EAGE 6th International Conference \& Exhibition, Saint Petersburg, Russia. Extended abstract. DOI:10.3997/2214-4609.20140307.

Marin, D., Escalona, A., Sliwinska, K., Nøhr-Hansen, H., Mordasova, A., 2016a. Sequence stratigraphy and lateral variability of Lower Cretaceous clinoforms in the SW Barents Sea AAPG Bull. doi: 10.1306/10241616010.

Marin, D., Escalona, A., Grundvåg, S.-A., Olaussen, S., Sliwinska, K., 2016b. Depositional history of the Lower Cretaceous sequences in the southwestern Barents Sea. International Arctic Geological Conference (IAGC)/Norwegian Petroleum Society (NPF): Arctic Exploration - Understanding the Barents Sea potential, Troms $\varnothing$, Norway, May 31th-June 2nd.

Michels, K.H., Kudrass, H.R., Hübscher, C., Suckow, A., Wiedicke, M., 1998. The submarine delta of the Ganges-Brahmaputra: cyclone-dominated sedimentation patterns. Mar. Geol. 149, 133-154.

Midtkandal, I., Nystuen, J.P., 2009. Depositional architecture of a low-gradient ramp shelf in an epicontinental sea: the Lower Cretaceous of Svalbard. Basin Res. 21, 655-675.

Midtkandal, I., Nystuen, J.P., Nagy, J., 2007. Paralic sedimentation on an epicontinental ramp shelf during a full cycle of relative sea-level fluctuation; the Helvetiafjellet Formation in Nordenskiöld Land, Spitsbergen. Nor. J. Geol. 87, 343-359.

Midtkandal, I., Nystuen, J.P., Nagy, J., Mørk, A., 2008. Lower Cretaceous lithostratigraphy across a regional subaerial unconformity in Spitsbergen: the Rurikfjellet and Helvetiafjellet formations. Nor. J. Geol. 88, 287-304.

Midtkandal, I., Svensen, H., Planke, S., Corfu, F., Polteau, S., Torsvik, T., Faleide, J.I., Grundvåg, S.A., Selnes, H., Olaussen, S. In review. The Aptian oceanic anoxic event (OAE1a) in Svalbard and the age of the Barremian-Aptian boundary. Palaeogeography, Palaeoclimatology, Palaeoecology.

Miller, E. L., J. Toro, G. Gehrels, J. M. Amato, A. Prokopiev, M. I. Tuchkova, V. V. Akinin, T. A. Dumitru, T. E. Moore, M. P. Cecile, 2006. New insights into Arctic paleogeography and tectonics from U-Pb detrital zircon geochronology. Tectonics 25, TC3013. DOI:10.1029/ 2005TC001830.

Mitchum Jr.,R., Vail. P., Sangree, J., 1977. Seismic stratigraphy and global changes of sea level: Part 6. Stratigraphic interpretation of seismic reflection patterns in depositional sequences: Section 2. Application of seismic reflection configuration to stratigraphic interpretation. In: Peyton, C.E. (Ed.), Seismic stratigraphy - applications to hydrocarbon exploration. AAPG Memoir 26, 117-133.

Mørk, A., Dallmann, W.K., Dypvik, H., Johannessen E.P., Larssen, G.B., Nagy, J., Nøttvedt, A., Olaussen, S., Pčelina, T.M., Worsley, D., 1999. Mesozoic lithostratigraphy. In: Dallmann, W.K. (Ed.), Lithostratigraphic Lexicon of Svalbard. Norsk Polarinstitutt (Troms $\varnothing$ ), 127-214.

Myrow, P. M., Fischer, W., GoodgeJ. W., 2002. Wave-modified turbidites: combined-flow shoreline and shelf deposits, Cambrian, Antarctica. J. Sed. Res. 72, 641-656. 
Mørk A., 1978. Observations on the stratigraphy and structure of the inner Hornsund area. Norsk Polarinstitutt Årbok 1977, 61-70.

Nagy J., 1970. Ammonite faunas and stratigraphy of Lower Cretaceous (Albian) rocks in southern Spitsbergen. Norsk Polarinstitutt Skrifter 152, 1-58.

Neill, C.F., Allison, M.A., 2005. Subaqueous deltaic formation on the Atchafalaya Shelf, Louisiana. Mar. Geol. 214, 411-430.

Nemec W., 1992. Depositional controls on plant growth and peat accumulation in a braidplain delta environment: Helvetiafjellet Formation (Barremian-Aptian), Svalbard. In: McCabe, P.J., Parish, J.T. (Eds.), Controls on the distribution and quality of cretaceous coals. Boulder Colorado, Geol. Soc. Spec. Paper 267, 209-226.

Nemec, W., Steel, R.J., Gjelberg, J., Collinson, J.D., Prestholm, E., Øxnevad, I.E., 1988. Anatomy of collapsed and re-established delta front in Lower Cretaceous of Eastern Spitsbergen: gravitational sliding and sedimentation process. AAPG Bull. 72, 454-476.

Nikishin, A.M., Malyshev, N.A., Nikishin, V.A., Soloviev, A.V., Aleksandrova, G.N., Escalona, A., 2014. Aptian paleogeography of North Kara Sea region: provenance analyses based on detrital zircon ages from Vize Island Aptian sandstones. AAPG Search and Discovery Article \#10566, p. 29.

Nilsen, K. T., Vendeville, B.C., Johansen, J.-T., 1995. Influence of regional tectonics on halokinesis in the Nordkapp Basin, Barents Sea. In: Jackson, M. P. A., Roberts, D. G., Snelson, S. (Eds.), Salt tectonics: a global perspective. AAPG Memoir 65, 413-436.

Nittrouer, C. A., Kuehl, S.A., Figueiredo, A.G., Allison, M.A., Sommerfield, C.K., Rine, E., Faria, E.C., Silveira, O.M., 1996. The geological record preserved by Amazon shelf sedimentation. Continental Shelf Res. 16, 817-841.

Nøttvedt, A., Cecchi, M., Gjelberg, J.G., Kristensen, S.E., Lønøy, A., Rasmussen. A., Rasmussen. E., Skott, P.H., van Veen, P.M., 1992. Svalbard-Barents Sea correlation: a short review. In: Vorren, T.O., Bergsager, E., Dahl-Stamnes, Ø.A., Holter, E., Bohansen, B., Lie, E., Lund, T.B. (Eds.), Arctic Geology and Petroleum Potential. NPF Spec. Publ 2, Elsevier, Amsterdarn, 363-375.

Nøhr-Hansen, H., 1993. Dinoflagellate cyst stratigraphy of the Barremian to Albian, Lower Cretaceous, East Greenland. Geol. Greenland. Sur. Bull. 166, pp. 171.

Nøhr-Hansen, H., 2012. Palynostratigraphy of the Cretaceous-lower Palaeogene sedimentary succession in the Kangerlussuaq Basin, southern East Greenland. Review of Palaeobotany and Palynology 178, 59-90.

Onderdonk, N., Midtkandal, I., 2010. Mechanisms of collapse of the Cretaceous Helvetiafjellet formation at Kvalvågen, eastern Spitsbergen. Mar. Petrol. Geol. 27, 2118-2140.

Osmundsen, P.T., Ebbing, J., 2008. Styles of extension offshore mid-Norway and implications for mechanisms of crustal thinning at passive margins. Tectonics 27, TC6016. DOI: 10.1029/2007TC002242.

Patruno, S., Hampson, G.J., Jackson, C., A.-L., 2015. Quantitative characterisation of deltaic and subaqueous clinoforms. Earth-Sci. Rev. 142, 79-119. 
Pattison, S. A. J., 2005. Storm-influenced prodelta turbidite complex in the Lower Kenilworth Member at Hatch Mesa, Book Cliffs, Utah, U.S.A.: implications for shallow marine facies models. J. Sed. Res. 75, 420-439.

Parker J.R., 1967. The Jurassic and Cretaceous Sequence in Spitsbergen. Geol. Mag. 104, 487-505.

Pinous, O. V., Karogodin, Y. N., Ershov, S. V., Sahagian, D. L., 1999. Sequence stratigraphy, facies and sea level change of the Hauterivian productive complex, Priobskoe oil field (West Siberia). AAPG Bull. 83, 972-989.

Pinous, O., Levchuk, M., Sahagian, D., 2001. Regional synthesis of the productive Neocomian complex of West Siberia: Sequence stratigraphic framework. AAPG Bull. 85, 1713-1730.

Polteau, S., Hendriks, B.W.H., Planke, S., Ganerød, M., Corfu, F., Faleide, J.I., Midtkandal, I., Svensen, H.S., Myklebust, R., 2015. The Early Cretaceous Barents Sea Sill Complex: Distribution, 40Ar/ 39Ar geochronology, and implications for carbon gas formation. Palaeogeography, Palaeoclimatology, Palaeoecology. DOI: 10.1016/j.palaeo.2015.07.007.

Pratson, L., Swenson, J., Kettner, A., Fedele, J., Postma, G., Niedoroda, A., Friedrichs, C., Syvitski, J., Paola, C., Steckler, M., Hutton, E., Reed, C., Van Dijk, M., Das. H., 2004. Modelling continental shelf formation in the Adriatic and elsewhere. Oceanography 17, 118-131.

Rojo, L.A. Escalona, A., Schultze, L., Sayghe, S.A., 2015. Interpretation, modeling, and halokinetic evolution of salt diapirs in the Nordkapp Basin. EAGE 77th International Conference \& Exhibition, Madrid, Spain. Extended abstract. DOI:10.3997/2214-4609.201412529.

Rokoengen, K., Mørk, A., Mørk, M.B.E., Smelror, M., 2005. The irregular base Cretaceous reflector offshore Mid Norway: a possible result of the Mjølnir impact in the Barents Sea? Nor. Geol. Sur. Bull. $443,19-27$.

Sattar, N., Juhlin, C., Koyi, H., Ahmad, N., 2017. Seismic stratigraphy and hydrocarbon prospectivity of the Lower Cretaceous Knurr Sandstone lobes along the southern margin of Loppa High, Hammerfest Basin, Barents Sea. Mar. Petrol. Geol. 85, 54-69.

Seilacher, A., 1982. General remarks about event deposits. In: Einsele, G., Seilacher, A. (Eds.), Cyclic and event stratification. Berlin, Springer-Verlag, p. 161-174.

Seldal, J., 2005. Lower Cretaceous: the next target for oil exploration in the Barents Sea? In: Doré, A. G., Vining, B. A. (Eds.), Petroleum Geology: North- West Europe and Global Perspectives.

Proceedings of the 6th Petroleum Geology Conference, 231-240. Petroleum Geology Conferences Ltd. Published by the Geological Society, London.

Senger, K., Tveranger, J., Ogata K., Braathen, A., Planke, S., 2014. Late Mesozoic magmatism in Svalbard: a review. Earth-Sci. Rev. 139, 123-144.

Śliwińska, K.K., Nøhr-Hansen, H. Jelby, M.E., Grundvåg, S.-A., Olaussen, S., 2016. Dinocyst biostratigraphy of the Lower Cretaceous succession of central and southeastern Spitsbergen. European Geosciences Union (EGU) General Assembly, Vienna, Austria. Geophysical Res. Abstracts Vol. 18, EGU2016-13858. 
Smelror, M., Mørk A., Monteil, E., Rutledge, D., Leereveld, H., 1998. The Klippfisk Formation - A new lithostratigraphic unit of Lower Cretaceous platform carbonates on the Western Barents Shelf. Polar Res. 17, 181-202.

Solheim, A. \& Kristoffersen, Y. 1984. The physical environment Western Barents Sea 1:1500 000, Sheet B: Sediments above the upper regional unconformity: thickness, seismic stratigraphy and outline of the glacial history. Norsk Polarinstitutt Skrifter 179B. pp. 26.

Steel, R.J., Worsley, D., 1984. Svalbard's post-Caledonian strata - an atlas of sedimentational patterns and palaeogeographic evolution. In: Spencer, A.M. (Ed.), Petroleum Geology of the North European Margin. Norwegian Petroleum Society. Graham and Trotman Ltd, pp. 109-135.

Steel, R.J., Gjelberg, J., Haarr, G., 1978. Helvetiafjellet Formation (Barremian) at Festningen, Spitsbergen - a field guide. Norsk Polarinstitutt Årbok 1978, 111-128.

Steel, R.J., Crabaugh, J., Schellpepper, M., Mellere, D., Plink-Björklund, P., Deibert, J., Løseth, T., 2000. Deltas vs. rivers on the shelf edge: their relative contributions to the growth of shelf-margins and basin-floor fans (Barremian and Eocene, Spitsbergen). In: P. Weimer et al. (Eds.), Deep-water reservoirs of the world. Proceedings of the GCSSEPM Foundation 20th Annual Research Conference, 981-1009.

Stewart, D. J., Berge, K. \& Bowlin, B. 1995. Exploration trends in the Southern Barents Sea. In: Hanslien, S. (Ed.), Petroleum Exploration and Exploitation in Norway. Elsevier, Amsterdam, NPF Spec. Publ. 4, 253-276.

Swenson, J.B., Paola, C., Pratson, L., Voller, V.R., Murray, A.B., 2005. Fluvial and marine controls on combined subaerial and subaqueous delta progradation: morphodynamic modeling of compoundclinoform development. J. Geophys. Res. 110, 1-16.

Swift, D. J. P., Thorne, J.A., 1991. Sedimentation on continental margins, I: a general model for shelf sedimentation. In: Swift, D.J.P., Oertel, G.F., Tillman, R.W., Thorne, J.A. (Eds.), Shelf sand and sandstone bodies. IAS Spec. Publ. 14, 3-31.

Torsvik, T.H., Carlos, D., Mosar, J., Cocks, L.R.M., Malme, T., 2002. Global reconstructions and North Atlantic palaeogeography 400 Ma to Recent. In: Eide, E.A. (Ed.), BATLAS - Mid Norway plate reconstructions atlas with global and Atlantic perspectives. Geol. Surv. Nor., pp. 18-39.

Traykovski, P., Geyer, W.R., Irish, J.D., Lynch, J.F., 2000. The role of wave induced density-driven fluid mud flows for cross-shelf transport on the Eel River continental shelf. Continental Shelf Res. 20, 2113-2140.

Ulmishek, G. F., 2003. Petroleum geology and resources of the West Siberian Basin, Russia. USGS Bull. 2201-G, 1-49.

Van Wagoner, J.C., Mitchum, R.M., Campion, K.M., Rahmanian, V.D., 1990. Siliciclastic sequence stratigraphy in well logs, cores, and outcrops: concepts for high resolution correlation of time and facies. AAPG Methods in Exploration Series 7, 55 p.

Walsh, J. P., Nittrouer, C.A., Palinkas, C.M., Ogston, A.S., Sternberg, R.W., Brunskill, G. J., 2004. Clinoform mechanics in the Gulf of Papua, New Guinea. Continental Shelf Res. 24, 2487-2510. 
Vickers, M.L., Price, G.D., Jerrett, R.M., \& Watkinson, M., 2016. Stratigraphic and geochemical expression of Barremian-Aptian global climate change in Arctic Svalbard. Geosphere 12, 1-12. doi:10.1130/GES01344.1.

Worsley, D., Johansen, R., Kristensen, S.E., 1988. The Mesozoic and Cenozoic succession of Tromsøflaket. In: Dalland, A., Worsley, D., Ofstad, K. (Eds.), A lithostratigraphic scheme for the Mesozoic and Cenozoic succession offshore mid- and northern Norway. NPD Bull. 4, 42-65.

Wierzbowski, A., Hryniewicz, K., Hammer, Ø., Nakrem, H.A., Little, C.T.S., 2011. Ammonites from hydrocarbon seep carbonate bodies from the uppermost Jurassic-lowermost Cretaceous of Spitsbergen and their biostratigraphical importance. N. Jb. Geol. Paläont. Abh. 262, 267-288.

Wright, L.D., Friedrichs, C.T., Kim, S.C., Scully, M.E., 2001. Effects of ambient currents and waves on gravity-driven sediment transport on continental shelves. Mar. Geol. 175, 25-45.

Yang, Z.S., Liu, J.P., 2007. A unique Yellow River-derived distal subaqueous delta in the Yellow Sea. Mar. Geol. 240, 169-176.

Zhang, X., Omma, J., Pease, V., Scott, R., 2013. Provenance of Late Paleozoic-Mesozoic Sandstones, Taimyr Peninsula, the Arctic. Geosciences 3, 502-527.

Århus, N., 1991a. The transition from deposition of condensed carbonates to dark claystones in the Lower Cretaceous succession of the southwestern Barents Sea. Nor. J. Geol. 71, 259-263

Århus, N., 1991b. Dinoflagellate cyst stratigraphy of some Aptian and Albian sections from North Greenland, southeastern Spitsbergen and the Barents Sea. Cret. Res. 12, 209-225.

Århus, N., 1992. Some dinoflagellate cysts from the Lower Cretaceous of Spitsbergen. Grana 31, 305314.

Århus, N., Kelly, S. R. A., Collins, J. S. H., Sandy, M. R., 1990. Systematic paleontology and biostratigraphy of two Early Cretaceous condensed sections from the Barents Sea. Polar Res. 8, 165194. 


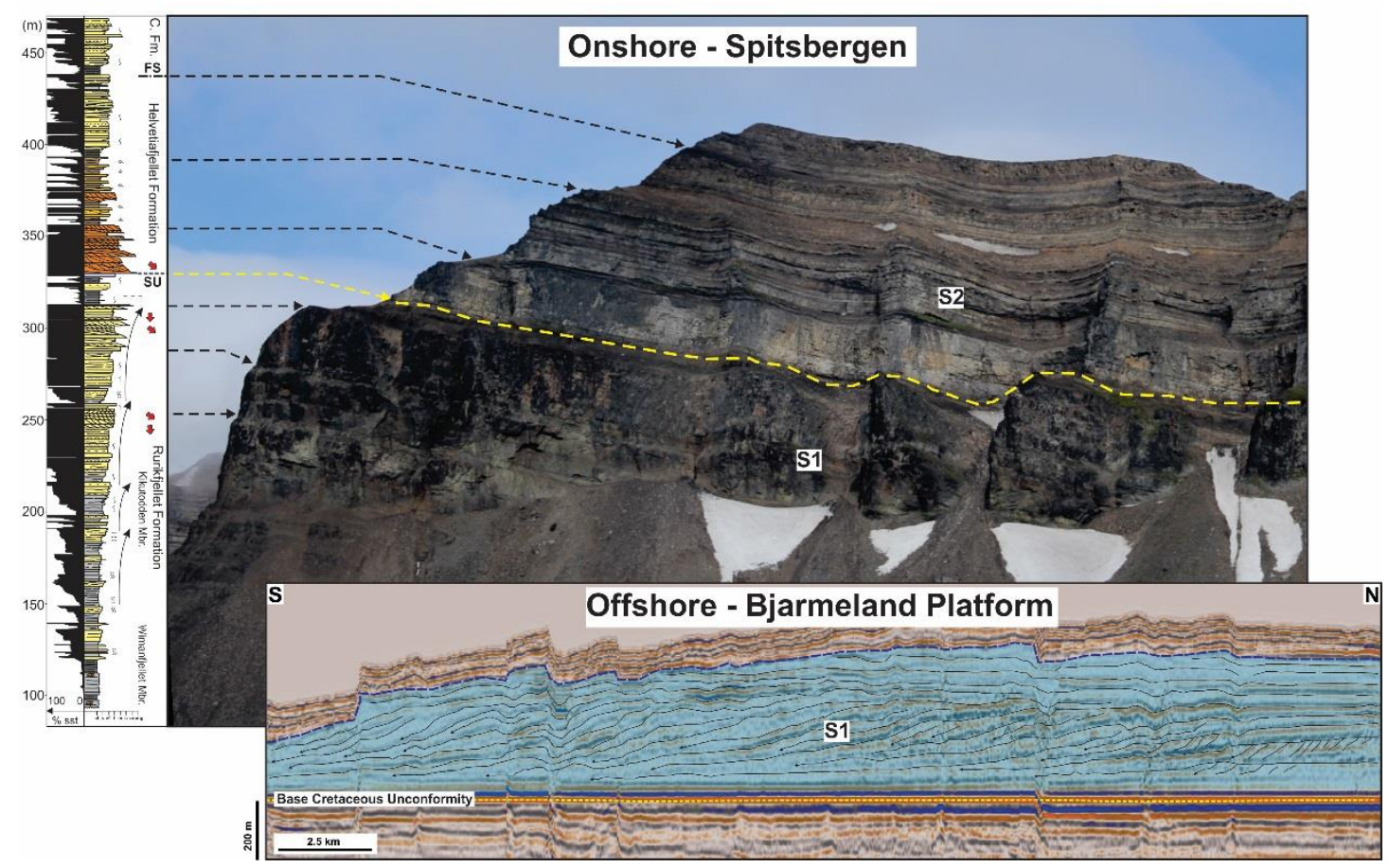

\section{Graphical abstract}

